\title{
Article \\ A Compromised Decision-Making Approach to Third-Party Logistics Selection in Sustainable Supply Chain Using Fuzzy AHP and Fuzzy VIKOR Methods
}

\author{
Chia-Nan Wang ${ }^{1}$, Ngoc-Ai-Thy Nguyen ${ }^{1, *}$, Thanh-Tuan Dang ${ }^{1,2, *}$ and Chen-Ming Lu ${ }^{3, *}$ \\ 1 Department of Industrial Engineering and Management, National Kaohsiung University of Science and \\ Technology, Kaohsiung 80778, Taiwan; cn.wang@nkust.edu.tw \\ 2 Department of Logistics and Supply Chain Management, Hong Bang International University, \\ Ho Chi Minh 723000, Vietnam \\ 3 Shanghai Jiao Tong University, Shanghai 200081, China \\ * Correspondence: i109143106@nkust.edu.tw (N.-A.-T.N.); i108143106@nkust.edu.tw (T.-T.D.); \\ cheng.ml1092@gmail.com (C.-M.L.)
}

check for updates

Citation: Wang, C.-N.; Nguyen, N.-A.-T.; Dang, T.-T.; Lu, C.-M. A Compromised Decision-Making Approach to Third-Party Logistics Selection in Sustainable Supply Chain Using Fuzzy AHP and Fuzzy VIKOR Methods. Mathematics 2021, 9, 886. https://doi.org/10.3390/math9080886

Academic Editors: Santoso Wibowo and William Guo

Received: 25 March 2021

Accepted: 14 April 2021

Published: 16 April 2021

Publisher's Note: MDPI stays neutral with regard to jurisdictional claims in published maps and institutional affiliations.

Copyright: (c) 2021 by the authors. Licensee MDPI, Basel, Switzerland. This article is an open access article distributed under the terms and conditions of the Creative Commons Attribution (CC BY) license (https:// creativecommons.org/licenses/by/ $4.0 /)$.

\begin{abstract}
With the effects of the COVID-19 pandemic, the e-commerce trend is driving faster, significantly impacting supply chains around the world. Thus, the importance of logistics and supply chain functions has been amplified in almost every business that ships physical goods. In Vietnam, the logistics service sector has seen rapid expansion. Since more and more businesses are seeking third-party logistics (3PL) providers to outsource the logistics functions, this article aims to offer decision-makers an integrated and consistent model for evaluating and selecting the most efficient 3PLs. To this end, the authors exploit a hybrid multi-criteria method which is fuzzy analytic hierarchy process (FAHP) and fuzzy vlsekriterijumska optimizacija i kompromisno resenje (FVIKOR) while examining the most influential and conflicting criteria regarding economic, service level, environmental, social, and risk aspects. Fuzzy information in the natural decision-making process is considered, linguistic variables are used to mitigate the uncertain levels in the criteria weights. First, FAHP (the weighting method) is adopted to evaluate and calculate each criterion's relative significant fuzzy weight. FVIKOR (the compromised ranking method) is then used to rank the alternatives. The combination of FAHP and FVIKOR methods provides more accurate ranking results. As a result, reliability and delivery time, voice of customer, logistics cost, network management, and quality of service are the most impactful factors to the logistics outsourcing problem. Eventually, the optimized 3PLs were determined that fully meet the criteria of sustainable development. The developed integrated model offers the complete and robust 3PLs evaluation and selection process and can also be a powerful decision support tool for other industries.
\end{abstract}

Keywords: logistics outsourcing; 3PL; FAHP; FVIKOR; triangular fuzzy number; decision-making; supply chain

\section{Introduction}

In today's diverse and fast-paced world, there are numerous ways for companies to achieve competitive advantages through the outsourcing of logistics and supply chain practices. Manufacturers, distribution firms, and those with supply chains have all been shown to benefit from outsourcing to third-party logistics (3PL) providers. 3PL refers to the process by which a manufacturer outsources logistics and distribution functions. Inventory management, cross-docking, door-to-door distribution, and product packaging are all facilities that a 3PL business provides [1]. Globalization has aided in the establishment of a global network of industrial activities. The demand for 3PL services is expected to rise in order to keep it thriving. The reach of 3PL services is expected to expand over the forecast period, as supply chain efficiency improvements in terms of cost and reliability 
can be achieved with the aid of 3PL companies' managerial and information technology expertise. Numerous critical factors have stimulated the growth of the 3PL market, such as the increase in trading activities due to globalization, fueled by dynamic business markets and global economic growth. Various trade-related practices are complex to tackle, but they are on the rise as a result of globalization. Thus, 3PL companies help companies to keep track of and control these activities. Another top impacting factor is the rise in focus of manufacturers and retailers on core competencies. Manufacturers or retailers find it challenging to deal with all affairs based on their abilities while maintaining core competencies in the industry [2]. 3PLs essentially give them the ability to focus on their primary functions, core businesses, and sub-contracting activities, such as logistics, which they have less expertise at, therefore providing a steadfast platform for outsourcing all or parts of the supply chain functions. For instance, 3PL companies can make better use of transportation assets to foster respective specialization in production and distribution by balancing the needs of multiple client shippers through transportation and distribution functions, leading to economies of scale. Furthermore, if a company lacks the technological capability to achieve its objectives, it is pivotal to outsource to 3PLs.

The growth of the 3PL service market has been accelerated due to the resonance of the e-commerce boom and increased reverse logistics operations. Faster, more reliable delivery, high inventory turnover, and inventory staged in forwarding locations near customers are all part of the e-commerce trend. There has been a massive influx of third-party logistics (3PL) companies to help sustain this incredibly complicated supply chain, offering a wide variety of services. 3PLs are often contacted for assistance with omnichannel e-commerce fulfillment, warehouse, and delivery facilities, while 3PLs invest in technology both to serve their clients and for their own use. The role of e-commerce has been further amplified and accelerated due to the present global crisis: the COVID-19 pandemic [3]. Since the outbreak of COVID-19, many shoppers are opting to buy online versus traveling to a physical store. The pandemic has also forced businesses to adapt to a fully digitalized business model to reach their consumer base. This boost in e-commerce creates challenges to supply chain operations, mainly last-mile delivery. Last-mile fulfillment is one of the most challenging and expensive aspects of a supply chain to manage [4]. Consumers are becoming more accustomed to receiving services that are both fast and efficient. For shippers, the finalmile highlights key factors and complex challenges as part of the overall transportation space [5]. On the pulse of adapting to growth in the logistics industry, e-commerce is seeing many of these market changes far before the consumer experiences them. In this respect, 3PLs have tailored to new distribution models, suitable warehouse locations, expansion of transportation modes, and increased visibility demand for shippers. As a matter of fact, a lot of companies are turning to 3PL providers for retooling their supply chain, with a significant minority $(12.4 \%)$ of organizations plan to increase the use of 3PLs in the wake of COVID-19, according to a recent survey by the Business Continuity Institute [6].

Based on the above discussions, choosing a third-party logistics provider (3PL) is a huge decision, thus a significant problem for any firm. Evaluation and selection of appropriate 3PL is an indispensable part of building sustainable supply chain partnerships. The noted fact is that supply chain management and logistics services done well are viable strategies in an e-commerce business or any business succeeding. The process of selecting 3PL providers begins with the development of decision criteria for defining and assessing potential candidates that can satisfy the firm's service needs [7]. Industry experts give the assessment information of the potential alternatives within this context considering the chosen criteria such as quality, cost, capacity, flexibility time, delivery capability, and benefits and risks of the outsourcing decision. Moreover, it is necessary to find 3PLs that have made significant investments in state-of-the-art technologies. For instance, the 3PL provider should have the technology solution to sync warehousing inventory with the ordering system and platform, providing real-time information on availability. That type of visibility can help with tracking, ordering, and forecasting. On top of developing core businesses that maintain competition in supply chains and meet global needs in the economic environment, 
large firms are focusing on creating sustainable supply chains. In respect of that, social and environmental factors have become significant for creating a more green and resilient supply chain. Global warming and recent economic disasters have necessitated a greater need for more sustainable logistics services [8].

Owing to the characteristics of multifaceted decision-making problems, 3PL selection can be regarded as a complicated multi-criteria decision-making (MCDM) problem due to the availability of quantitative, qualitative, and multiple criteria in the natural decisionmaking process. Given the abovementioned importance of sustainable 3PL providers, there is sparse research to date that the 3PL selection problem developing countries, especially in Vietnam, according to our literature review. In Vietnam, logistics services' growth rate reaches $16-20 \%$ per year [9]. However, the logistics service industry's competitiveness is still low, and logistics costs are still very high at a rate of 20-25\% of Vietnam's GDP. Within this context, the 3PL solution can help reduce costs, boost sales, and build brand identity given Vietnam's size and diversity. According to Armstrong and Associates, the revenue of the 3PL market in Vietnam achieved a USD 4.1 billion in 2019 [10], ranking the third in Southeast Asia, just behind Indonesia (18.6) and Thailand (6.0). The remarkable growth of the 3PL market has come from the development of the e-commerce industry. In fact, the demand for 3PL is expected to escalate, as manufacturers and retailers aim to focus on their core businesses. Hence, they tend to outsource logistics services. As a result, evaluating and selecting optimized 3PL providers is an indispensable part of any firm's long-term strategies.

To this end, this article aims to provide a comprehensive and coherent evaluation model for assessing and ranking 3PL providers, more specifically, to solve the problem in Vietnam. A two-stage multi-criteria optimization model is presented for this purpose. Additionally, we consider the fuzziness in the decision data and group decision-making process to use linguistic variables in the AHP and VIKOR methods. Thus, in the first stage, FAHP is applied to evaluate and calculate each criterion's relative significant fuzzy weight. The fuzzy numbers in triangular forms were used to convert the qualitative content and ambiguity of parameters in the real-world decision-making process, which are generally represented in linguistic terms. According to the well-developed 3PL evaluation and selection literature, the authors define the list of criteria including economic, service level, environmental, social, and risk are dominant decision-making factors in 3PL selection. In detail, the list of 15 criteria is categorized as follows: economic (logistics cost, financial stability, IT and R\&D systems, network management), service level (quality of service, reliability and delivery time, flexibility and responsiveness), environmental (environmental pollution, ecological laws, green operation), social (health and safety, voice of customer, reputation), and risk (operational risk, financial risk). In the second stage, FVIKOR is developed to rank multiple alternatives based on the compromise solution approach that provides a maximum "group utility of the majority" and the minimum "individual regret of the opponent". Eventually, the author considered an empirical case study of 10 Vietnamese 3PL companies into the evaluation and selection process by using the prescribed approach.

One of the innovations of this study is to determine the best 3PL providers in Vietnam while considering the most influential and conflicting criteria in recent times, which has almost been missed in the literature. Methodologically, a combination of FAHP and FVIKOR has been done for the first time to solve the problem. In terms of applications, the developed integrated model can assist management stakeholders to better understand the entire process of 3PL assessment and selection from the standpoint of sustainability. Uncertain and vague judgments during the evaluation process were also addressed with linguistics terms and fuzzy theory to enhance the robust results. As a result, the evolved approach offers a complete, accurate, and effective decision-making method for the 3PL evaluation and selection.

The remnant of this paper is outlined as follows. Conducted research on outsourcing for logistics are reviewed and the gaps addressed by the current study are examined in the next section. Section 3 summarizes the materials and methods used in the research. 
Section 4 presents the result analysis of a case study in Vietnam. The paper is concluded in Section 5 by providing managerial insights and contributions of the research.

\section{Literature Review}

Recent literature review on the 3PL industry concerned sustainable development with approaches where the economic, environmental, and social dimensions of a business are harmonized. For example, Raut et al. [11] emphasized that ecological, social, and economic dimensions must be considered to obtain well-rounded sustainable 3PLs. The authors proposed a hybrid MCDM model using the data envelopment analysis (DEA) and analytic network process (ANP) to help decision makers assess and obtain the optimized 3PLs from the environmental sustainability perspective. Findings showed that better transportation planning, inventory and warehouse management, lower inventory costs, and sustainable supply chain activities are all aided by eco-friendly transportation and 3PLs. In addition to investigating the economic effect (pricing policies) regarding the activities of 3 PLs, Jamali and Rasti-Barzoki [12] simultaneously considered two significant sustainable indicators: green transport by lowering carbon emissions and consumer satisfaction by providing product time. In this research, the effects of the 3PLs in the sustainable supply chain were investigated using a game-theoretical approach. The term "green logistics outsourcing" is more than just a buzzword since today, organizations aim to minimize simultaneously the negative economic impacts of logistics policies and social factors such as pollution's effects on the environment. In light of this, Vazifehdan and Darestani [13] presented a combinational approach using the quality function deployment (QFD), fuzzy ANP, and superiority and inferiority ranking (SIR) methods to provide an assessing and ranking model for outsourcing green logistics. The proposed model was illustrated for a case study in the petrochemical industry, where the strategic outsourcing of green logistics is undoubtedly indispensable.

Approaches to logistics outsourcing are summarized in the latest review paper of Aguezzoul [14], in which the author classified the methodologies into five groups: MCDM techniques, statistical approaches, artificial intelligence, mathematical programming, and hybrid methods. According to the current systematic review, MCDM techniques are the most widely cited, and most of them combined with techniques from the same category or with other methods. However, most of the studies conducted on 3PLs are empirical and focus majorly on the benefits and risks of the outsourcing decision. Raut et al. [11] pointed out that there is limited literature that has used MCDM methods to analyze environment sustainability issues for 3PL assessment and selection, especially in developing countries context. Table 1 presents a literature review on the 3PL sector in terms of problem characteristics, approaches, and applied areas in the past decade, as well as indicating the gap proposed by the current study. As can be seen, the main MCDM methods used in the case of logistics outsourcing problems, which are analytic hierarchy process (AHP) [15-18], analytic network process (ANP) [11,13,19], VIKOR [19], technique for order preference by similarity to ideal solution (TOPSIS) [16,17,20-22], data envelopment analysis [11,22-24], and other MCDM methods $[25,26]$. 
Table 1. The summary of method approaches applied in relevant studies.

\begin{tabular}{|c|c|c|c|c|c|}
\hline No. & $\begin{array}{c}\text { Authors } \\
\text { [Reference] }\end{array}$ & Year & Problems Solved & $\begin{array}{c}\text { Method } \\
\text { Approaches }\end{array}$ & Applied Areas \\
\hline 1 & Hou and Su [15] & 2006 & Supplier selection & $\begin{array}{c}\mathrm{AHP} \text { and web } \\
\text { services-oriented }\end{array}$ & $\begin{array}{l}\text { Manufacturing } \\
\text { industry in UK }\end{array}$ \\
\hline 2 & $\begin{array}{c}\text { Büyüközkan et al. } \\
{[16]}\end{array}$ & 2008 & $\begin{array}{l}\text { Strategic alliance in } \\
\text { e-logistics partner }\end{array}$ & $\begin{array}{c}\text { Fuzzy AHP, fuzzy } \\
\text { TOPSIS }\end{array}$ & $\begin{array}{l}\text { Electronic industry } \\
\text { in Turkish }\end{array}$ \\
\hline 3 & Kannan et al. [20] & 2009 & $\begin{array}{l}\text { Outsourcing } \\
\text { reverse logistics }\end{array}$ & ISM, fuzzy TOPSIS & $\begin{array}{l}\text { Battery production } \\
\text { in India }\end{array}$ \\
\hline 4 & $\begin{array}{c}\text { Liou and Chuang } \\
{[19]}\end{array}$ & 2010 & $\begin{array}{l}\text { Selection of } \\
\text { outsourcing } \\
\text { providers }\end{array}$ & $\begin{array}{l}\text { DEMATEL, ANP, } \\
\text { VIKOR }\end{array}$ & $\begin{array}{c}\text { Airline industry in } \\
\text { Taiwan }\end{array}$ \\
\hline 5 & $\begin{array}{c}\text { Perçin and Min } \\
\text { [25] }\end{array}$ & 2013 & $\begin{array}{l}\text { Optimal selection } \\
\text { of logistics parties }\end{array}$ & $\begin{array}{l}\text { QFD, fuzzy linear } \\
\text { regression }\end{array}$ & $\begin{array}{c}\text { Automobile } \\
\text { industry in Turkey }\end{array}$ \\
\hline 6 & Senthil et al. [17] & 2014 & $\begin{array}{c}\text { Reverse logistics } \\
\text { contractor } \\
\text { evaluation }\end{array}$ & $\begin{array}{l}\text { AHP, fuzzy } \\
\text { TOPSIS }\end{array}$ & $\begin{array}{c}\text { Plastics companies } \\
\text { in India }\end{array}$ \\
\hline 7 & $\begin{array}{c}\text { Ayhan and Kilic } \\
{[18]}\end{array}$ & 2015 & Supplier selection & Fuzzy AHP, MILP & $\begin{array}{l}\text { Gear motor } \\
\text { producers in } \\
\text { Turkey }\end{array}$ \\
\hline 8 & $\begin{array}{l}\text { Igoulalene et al. } \\
\text { [21] }\end{array}$ & 2015 & $\begin{array}{l}\text { Strategic partners } \\
\text { in supply chain }\end{array}$ & Fuzzy TOPSIS, GP & $\begin{array}{l}\text { Supply chain } \\
\text { management }\end{array}$ \\
\hline 9 & $\begin{array}{c}\text { Zarbakhshnia et al. } \\
\text { [26] }\end{array}$ & 2018 & $\begin{array}{c}\text { Reverse logistics } \\
\text { providers } \\
\text { evaluation }\end{array}$ & $\begin{array}{l}\text { Fuzzy SWARA, } \\
\text { fuzzy COPRAS }\end{array}$ & $\begin{array}{l}\text { Automobile } \\
\text { industry in Iran }\end{array}$ \\
\hline 10 & Raut et al. [11] & 2018 & $\begin{array}{l}\text { Evaluating and } \\
\text { selecting logistics } \\
\text { providers }\end{array}$ & DEA, ANP & $\begin{array}{l}\text { Supply chain } \\
\text { management }\end{array}$ \\
\hline 11 & $\begin{array}{c}\text { Rashidi and } \\
\text { Cullinane [22] }\end{array}$ & 2019 & $\begin{array}{c}\text { Sustainable } \\
\text { sourcing strategy }\end{array}$ & $\begin{array}{c}\text { Fuzzy DEA, fuzzy } \\
\text { TOPSIS }\end{array}$ & $\begin{array}{l}\text { Logistics industry } \\
\text { in Sweden }\end{array}$ \\
\hline 12 & $\begin{array}{c}\text { Vazifehdan and } \\
\text { Darestani [13] }\end{array}$ & 2019 & $\begin{array}{l}\text { Assessing and } \\
\text { ranking the } \\
\text { outsourcing green } \\
\text { logistics }\end{array}$ & QFD, fuzzy ANP & $\begin{array}{l}\text { Petrochemical } \\
\text { industry in Iran }\end{array}$ \\
\hline 13 & Deng et al. [23] & 2020 & $\begin{array}{c}\text { Performance } \\
\text { evaluation index } \\
\text { system }\end{array}$ & $\begin{array}{l}\text { PCA, DEA, Tobit } \\
\text { regression }\end{array}$ & $\begin{array}{l}\text { China's logistics } \\
\text { industry }\end{array}$ \\
\hline 14 & $\begin{array}{l}\text { Davoudabadi et al. } \\
\text { [24] }\end{array}$ & 2020 & $\begin{array}{l}\text { Multiple green } \\
\text { supplier selection }\end{array}$ & $\begin{array}{l}\text { Entropy, DEA, } \\
\text { PCA }\end{array}$ & $\begin{array}{l}\text { Supply chain } \\
\text { management }\end{array}$ \\
\hline 15 & This paper & 2021 & $\begin{array}{c}\text { Evaluation and } \\
\text { selection of } \\
\text { logistics providers }\end{array}$ & $\begin{array}{l}\text { DEA, fuzzy AHP, } \\
\text { fuzzy TOPSIS }\end{array}$ & $\begin{array}{c}\text { Logistics service in } \\
\text { Vietnam }\end{array}$ \\
\hline
\end{tabular}

Abbreviations: analytic hierarchy process (AHP), technique for order preference by similarity to ideal solution (TOPSIS), interpretive structural modeling (ISM), decision-making trial and evaluation laboratory (DEMATEL), analytical network process (ANP), vlsekriterijumska optimizacija i kompromisno resenje (VIKOR), quality function deployment (QFD), mixed integer linear programming (MILP), goal programming (GP), step-wise weight assessment ratio analysis (SWARA), complex proportional assessment of alternatives (COPRAS), data envelopment analysis (DEA), principal component analysis (PCA).

It is noteworthy that when choosing MCDM methods, it is prudent to select methods of normalization and other parameters, as each method and combination brings different results [27]. Among well-known weighting methods, AHP has been the most commonly used due to its popularity and applicability. For ranking methods, TOPSIS and VIKOR techniques, based on the distance from the ideal solution, have become very popular in the field [28]. In the last few decades, fuzzy TOPSIS was used in a very broad spectrum of areas, 
with implementations in the defense industry [29]. Group decision-making is a vital point of a fuzzy TOPSIS technique, where multiple experts influence the final decision. Meanwhile, the VIKOR method of compromise ranking determines a compromise solution, providing a maximum "group utility" for the "majority" and a minimum of an individual regret for the "opponent". For VIKOR, rankings obtained using any normalization methods could be even reversed in comparison to rankings obtained using VIKOR without normalization, while the TOPSIS method's normalized values by vector normalization may be dependent on the evaluation unit.

In this paper, the authors propose an integrated approach of fuzzy analytic hierarchy process (FAHP), and fuzzy vlsekriterijumska optimizacija i kompromisno resenje (FVIKOR) for the 3PL selection problem. The AHP method is a multicriteria method of analysis based on an additive weighting process, in which several relevant attributes are represented through their relative importance [30-32]. The pairwise comparison method in the AHP is a powerful procedure to identify the importance of different factors to the objective. Its understandability in theory, simplicity in application, and robustness of its outcomes have been proven in practice and validated by a diverse range of decision-making problems. However, the shortcoming of the AHP method is that it does not take into account the uncertainty associated with the mapping of human judgment to a number by natural language. To solve this, the fuzzy AHP based on the fuzzy interval arithmetic with triangular fuzzy numbers has been integrated into many studies. For rankings, VIKOR method simultaneously ranks multiple alternatives based on the compromise solution approach that provides a maximum "group utility of the majority" as well as the minimum "individual regret of the opponent" [33]. Owing to the fuzziness in the decision data and group decision-making process, linguistic variables are also utilized in the VIKOR model to assess the weights of all criteria and the ratings of each alternative with respect to each criterion.

Thus, the authors aim to fill the gap in the existing literature by solving a case study of evaluating and selecting 10 potential 3PL providers in Vietnam. The main contributions of this paper are as follows: (1) a combined model using the FAHP and FVIKOR methods is devoted to the emerging research topic of sustainability in the 3PL selection problem; (2) a case study of assessing 10 potential 3PL providers in Vietnam is used to test the quality of the model; (3) the results reflect that the gap of applying the proposed method in the field of the 3PL industry is successfully addressed, and the integrated framework can be a powerful decision support tool for the evaluation and selection problem in any area.

\section{Materials and Methods}

\subsection{Research Flowchart}

The evaluation and selection of 3PLs can be analyzed as a multiple-criteria decisionmaking problem (MCDM), considering qualitative and quantitative multiple factors. Based on the generalized framework for multi-criteria method selection $[34,35]$, this paper proposes a hybrid multi-criteria optimization model to evaluate and select logistics providers, i.e., in decision-making units (DMUs). Figure 1 presents a flowchart of the research including two stages. In the first stage, FAHP is used to evaluate and calculate the relative significant fuzzy weight of each criterion. The list of criteria which are based on reviewing the recent relevant studies and expert interviews is presented in Table 2. It shows that economic, service level, environmental, social, and risk are dominant decision-making factors in 3PL selection. Besides economic aspects, 3PL services provider is supposed to increase customer satisfaction by timely delivering and maintaining high service level. However, in a rapidly evolving market environment where the focus is on green and sustainable supply chain management, fulfilling cost, time, and quality requirements is no longer sufficient. Social factors and environmental sustainability in the supply chain have recently received increasing attention. Thus, environmental, social, and economic dimensions must be examined to identify a well-rounded sustainable 3PL that can enhance supply chain performance. Consequently, the list of 15 criteria is defined including 
economic (logistics cost, financial stability, IT and R\&D systems, network management), service level (quality of service, reliability and delivery time, flexibility and responsiveness), environmental (environmental pollution, environmental laws, green operation), social (health and safety, voice of customer, reputation), and risk (operational risk, financial risk). In the second stage, FVIKOR is developed to assess identified ranking and choose the optimal alternative of 3PL.

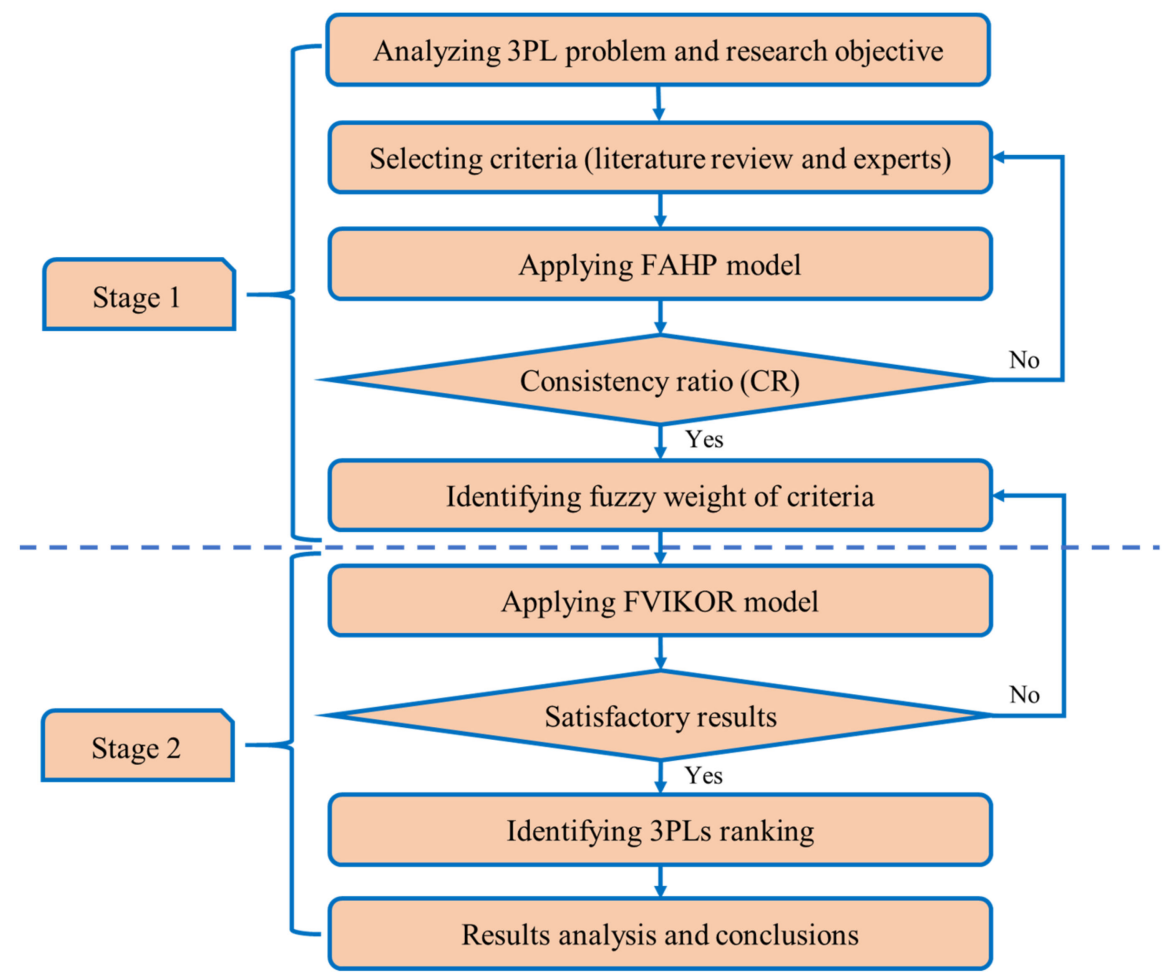

Figure 1. Research flowchart.

\subsection{Fuzzy AHP}

Zadeh [59] proposed the fuzzy set theory to deal with uncertainty MCDM problems. A triangular fuzzy number (TFN) is defined as $(a, b, c)$ which represents lower bound, middle value and upper bound, as shown in Figure 2, and Equation (1).

$$
\mu\left(\frac{x}{\widetilde{F}}\right)=\left\{\begin{array}{c}
(x-a) /(b-a), \quad a \leq x \leq b \\
(c-x) /(c-b), \quad b \leq x \leq c \\
0, \text { otherwise }
\end{array}\right.
$$

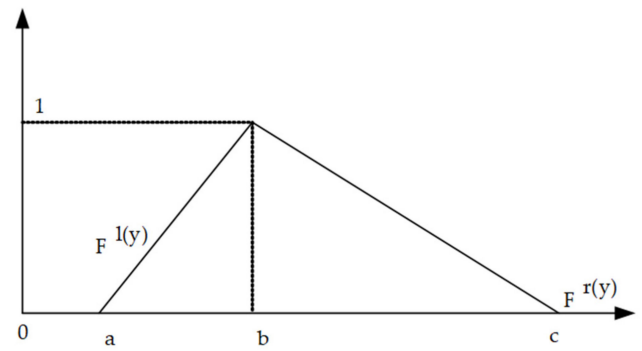

Figure 2. The membership function of TFN. 
Table 2. The list of criteria for 3PL selection and their definition.

\begin{tabular}{|c|c|c|c|c|}
\hline Main Criteria & Criteria & Goal & Definition & References \\
\hline \multirow{4}{*}{ 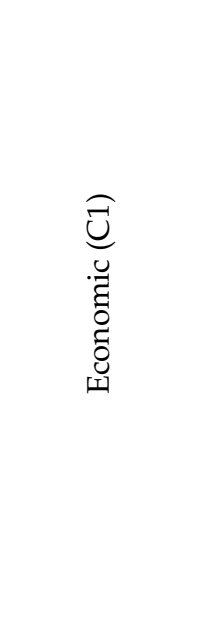 } & C11. Logistics cost & Min & $\begin{array}{l}\text { It refers to total cost of } \\
\text { outsourcing including } \\
\text { transportation and warehousing } \\
\text { cost, price, operating cost }\end{array}$ & [36-42] \\
\hline & $\begin{array}{l}\text { C12. Financial } \\
\text { stability }\end{array}$ & Max & $\begin{array}{l}\text { It is related to financial } \\
\text { statement, continuity of service, } \\
\text { and regular upgrade of the } \\
\text { logistics operation }\end{array}$ & {$[36,43-46]$} \\
\hline & $\begin{array}{l}\text { C13. IT and R\&D } \\
\text { systems }\end{array}$ & Max & $\begin{array}{l}\text { It includes innovative } \\
\text { technology capabilities, } \\
\text { information security, tracking } \\
\text { and tracing ability }\end{array}$ & {$[36,47,48]$} \\
\hline & $\begin{array}{l}\text { C14. Network } \\
\text { management }\end{array}$ & Max & $\begin{array}{l}\text { It is represented by location, } \\
\text { market coverage, relationship, } \\
\text { alliance strategy, international } \\
\text { scope }\end{array}$ & [49-53] \\
\hline \multirow{3}{*}{ 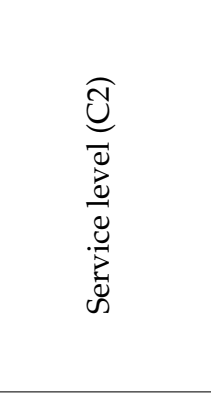 } & $\begin{array}{l}\text { C21. Quality of } \\
\text { service }\end{array}$ & Max & $\begin{array}{l}\text { It refers to quality control and } \\
\text { inspection, commitment to } \\
\text { continuous improvement }\end{array}$ & {$[36-42,54]$} \\
\hline & $\begin{array}{l}\text { C22. Reliability and } \\
\text { delivery time }\end{array}$ & Max & $\begin{array}{l}\text { It refers to on-time performance, } \\
\text { delivery speed, accuracy of } \\
\text { transshipment, responsibility to } \\
\text { customers }\end{array}$ & {$[36-42,54,55]$} \\
\hline & $\begin{array}{l}\text { C23. Flexibility and } \\
\text { responsiveness }\end{array}$ & Max & $\begin{array}{l}\text { Ability to adapt to customer } \\
\text { requirement change under } \\
\text { circumstances, professionalism }\end{array}$ & {$[36,37,39-41,56]$} \\
\hline \multirow{3}{*}{ 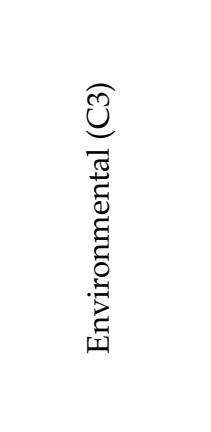 } & $\begin{array}{l}\text { C31. Environmental } \\
\text { pollution }\end{array}$ & Min & $\begin{array}{l}\text { It includes exhaust emission } \\
\text { volume, carbon emissions, traffic } \\
\text { noise }\end{array}$ & {$[39,41,57]$} \\
\hline & $\begin{array}{l}\text { C32. Environmental } \\
\text { laws }\end{array}$ & Max & $\begin{array}{l}\text { It refers to commitment in } \\
\text { capitalizing on pollution } \\
\text { reduction, total solid waste } \\
\text { productivity }\end{array}$ & {$[39,41]$} \\
\hline & C33. Green operation & Max & $\begin{array}{l}\text { It corresponds to green supply } \\
\text { chain, green distribution, green } \\
\text { packaging, green storage } \\
\text { management }\end{array}$ & {$[39,42,57]$} \\
\hline \multirow{3}{*}{ 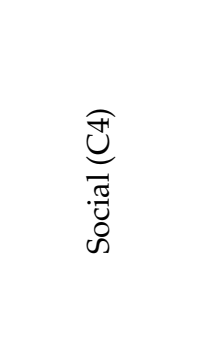 } & $\begin{array}{l}\text { C41. Health and } \\
\text { safety }\end{array}$ & Max & $\begin{array}{l}\text { It refers to occupational health } \\
\text { and safety awareness, preventive } \\
\text { action of working accidents }\end{array}$ & [39-41] \\
\hline & $\begin{array}{l}\text { C42. Voice of } \\
\text { customer }\end{array}$ & $\operatorname{Max}$ & $\begin{array}{l}\text { A sound of customer's feedback } \\
\text { about quality of products and } \\
\text { services }\end{array}$ & {$[39,40,42]$} \\
\hline & C43. Reputation & Max & $\begin{array}{l}\text { It refers to reputation of } \\
\text { providers, work experiences of } \\
\text { logistics providers }\end{array}$ & {$[37,40,42]$} \\
\hline \multirow{2}{*}{ 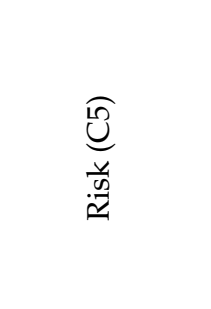 } & C51. Operational risk & Min & $\begin{array}{l}\text { It is related to failure and/or loss } \\
\text { in internal process or systems, } \\
\text { employee errors, security failure, } \\
\text { legal issues }\end{array}$ & {$[39,40,58]$} \\
\hline & C52. Financial risk & Min & $\begin{array}{l}\text { It refers to risk in cash flow } \\
\text { including total logistics cost, } \\
\text { resources, facilities, and financial } \\
\text { transactions }\end{array}$ & {$[36,38]$} \\
\hline
\end{tabular}


The representative of each level of membership function is presented, Equation (2).

$$
\widetilde{F}=\left(F^{l(y)}, F^{r(y)}\right)=[a+(b-a) y, c+(b-c) y], y \in[0,1]
$$

where $F^{l(y)}, F^{r(y)}$ are two sides of the fuzzy number.

The fuzzy analytical hierarchy process (FAHP), an extension of AHP, overcomes the drawbacks of AHP and solves many MCDM problems under fuzzy conditions. Table 3 shows the linguistic expression for the fuzzy scale and allocated TFN. The procedures of FAHP are presented below [60,61].

Table 3. Linguistic variable values in FAHP model.

\begin{tabular}{ccc}
\hline Level & Linguistics Variables & Corresponding TFNs \\
\hline 1 & Equal importance & $(1,1,1)$ \\
2 & Weak importance & $(1,2,3)$ \\
3 & Not bad & $(2,3,4)$ \\
4 & Preferable & $(3,4,5)$ \\
5 & Importance & $(4,5,6)$ \\
6 & Fairly importance & $(5,6,7)$ \\
7 & Very important & $(6,7,8)$ \\
8 & Absolute & $(7,8,9)$ \\
9 & Perfect & $(8,9,10)$ \\
\hline
\end{tabular}

Step 1: Suppose that a decision group has $K$ experts. An integrated fuzzy pairwise comparison matrix can be formulated using the geometrical aggregation, as Equation (3).

$$
\widetilde{D}\left(\begin{array}{cccc}
1 & \widetilde{f_{12}} & \cdots & \widetilde{f_{1 n}} \\
\widetilde{f_{21}} & 1 & \cdots & \widetilde{f_{2 n}} \\
\cdots & \cdots & \cdots & \cdots \\
\widetilde{f_{n 1}} & \widetilde{f_{n 2}} & \cdots & 1
\end{array}\right)=\left(\begin{array}{cccc}
1 & \widetilde{f_{12}} & \cdots & \widetilde{f_{1 n}} \\
1 / \widetilde{f_{21}} & 1 & \cdots & \widetilde{f_{2 n}} \\
\cdots & \cdots & \cdots & \cdots \\
1 / \widetilde{f_{n 1}} & \widetilde{f_{n 2}} & \cdots & 1
\end{array}\right)
$$

where $\widetilde{f}_{i j}=\left\{\begin{array}{c}\widetilde{9}^{-1}, \widetilde{8}^{-1}, \widetilde{7}^{-1}, \widetilde{6}^{-1}, \widetilde{5}^{-1}, \widetilde{4}^{-1}, \widetilde{3}^{-1}, \widetilde{2}^{-1}, \widetilde{1}^{-1}, \widetilde{1}, \widetilde{2}, \widetilde{3}, \widetilde{4}, \widetilde{5}, \widetilde{6}, \widetilde{7}, \widetilde{8}, \widetilde{9} \text { such that } i \neq j \\ 1 \text { such that } i=j\end{array}\right.$

Step 2: Fuzzy geometric mean of each criteria is computed by Equation (4).

$$
\widetilde{r_{i}}=\left(\prod_{j=1}^{n} \widetilde{f_{i j}}\right)^{1 / n} \text { such that } i=1,2, \ldots, n
$$

where $\widetilde{r_{i}}$ is the fuzzy geometric mean, and $\widetilde{f_{i j}}$ is fuzzy comparison value from group of decision-maker with respect to the $i^{\text {th }}$ dimension over the $j^{\text {th }}$ criterion.

Step 3: The fuzzy weight of each criteria is computed by Equation (5).

$$
\widetilde{w}_{i}=\widetilde{r}_{i}(\times)\left(\widetilde{r_{1}}(+) \widetilde{r_{2}}(+) \ldots(+) \widetilde{r_{n}}\right)^{-1}
$$

Step 4: Defuzzify the fuzzy weight using the average weight criteria $M_{i}$, as can be seen in Equation (6).

$$
M_{i}=\frac{\widetilde{w_{1}}(+) \widetilde{w_{2}}(+) \ldots(+) \widetilde{w_{n}}}{n}
$$

Step 5: The normalized weight criteria $N_{i}$ is computed by Equation (7).

$$
N_{i}=\frac{M_{i}}{\sum_{i=1}^{n} M_{i}}
$$

\subsection{Fuzzy VIKOR}

The compromise ranking method VIKOR (visekriterijumska optimizacija i kompromisno resenje) is introduced as an applicable method to deal with MCDM problems that 
have non-commensurable and conflicting criteria. The fuzzy VIKOR (FVIKOR), an extension of VIKOR under uncertain environments, uses linguistic expressions to evaluate the performance ratings of alternatives by criteria and to mitigate the uncertain levels in the criteria weights. The FVIKOR procedures are presented below [62].

Step 1: Define the fuzzy weights of criteria.

In this study, the fuzzy weights of criteria are calculated from the FAHP model.

Step 2: Build the performance fuzzy decision matrix according to the linguistic variable values in Table 4, Equations (8) and (9).

Table 4. Linguistics variable values of alternatives.

\begin{tabular}{cc}
\hline Linguistics Variables & Corresponding TFNs \\
\hline Very poor (VP) & $(0,1,2)$ \\
Poor (P) & $(1,2,3)$ \\
Medium poor (MP) & $(2,3.5,5)$ \\
Fair (F) & $(4,5,6)$ \\
Medium good (MG) & $(5,6.5,8)$ \\
Good (G) & $(7,8,9)$ \\
Very good (VG) & $(8,9,10)$ \\
\hline
\end{tabular}

$$
\begin{gathered}
\widetilde{M}=\left[\begin{array}{cccc}
\widetilde{x}_{11} & \widetilde{x}_{12} & \ldots & \widetilde{x}_{1 n} \\
\widetilde{x}_{21} & \widetilde{x}_{22} & \ldots & \widetilde{x}_{2 n} \\
\vdots & \vdots & \vdots & \ldots \\
\widetilde{x}_{m 1} & \widetilde{x}_{m 2} & \vdots & \widetilde{x}_{m n}
\end{array}\right] \text { such that } i=1,2, \ldots, m ; j=1,2, \ldots, n \\
\widetilde{x}_{i j}=\frac{1}{k}\left(\widetilde{x}_{i j}^{1}(+) \widetilde{x}_{i j}^{2}(+) \ldots(+) \widetilde{x}_{i j}^{k}\right)
\end{gathered}
$$

where $\widetilde{x}_{i j}^{k}$ represents fuzzy performance rating of alternative $A_{j}$ with respect to criteria $C_{i}$ by $k^{\text {th }}$ expert, and $\widetilde{x}_{i j}^{k}=\left(a_{i j}^{k}, b_{i j}^{k}, c_{i j}^{k}\right)$. Suppose there are $n$ alternatives to be evaluated with respect to $m$ criteria in FVIKOR model.

Step 3: Identify the fuzzy best value $\widetilde{f}_{i}^{+}=\left(a_{i}^{+}, b_{i}^{+}, c_{i}^{+}\right)$and fuzzy worst value $\widetilde{f}_{i}^{-}=$ $\left(a_{i}^{-}, b_{i}^{-}, c_{i}^{-}\right)$for all criteria, as can be seen in Equations (10) and (11).

$$
\begin{gathered}
\widetilde{f}_{i}^{+}=\max _{j} \widetilde{x}_{i j}, \widetilde{f}_{i}^{-}=\min _{j} \widetilde{x}_{i j} \text { for set of benefit criteria } \\
\widetilde{f}_{i}^{+}=\min _{j} \widetilde{x}_{i j}, \widetilde{f}_{i}^{-}=\max _{j} \widetilde{x}_{i j} \text { for set of cost criteria }
\end{gathered}
$$

Step 4: Calculate the normalized fuzzy difference $\widetilde{d}_{i j}$ between fuzzy performance rating $\widetilde{x}_{i j}$ and fuzzy best value $\widetilde{f}_{i}^{+}$, or fuzzy worst value $\widetilde{f}_{i}^{-}$, Equations (12) and (13).

$$
\begin{gathered}
\widetilde{d}_{i j}=\left(\widetilde{f}_{i}^{+}-\widetilde{x}_{i j}\right) /\left(c_{i}^{+}-a_{i}^{-}\right) \text {for set of benefit criteria } \\
\widetilde{d}_{i j}=\left(\widetilde{x}_{i j}-\widetilde{f}_{i}^{+}\right) /\left(c_{i}^{-}-a_{i}^{+}\right) \text {for set of cost criteria }
\end{gathered}
$$


Step 5: Calculate the separation $\widetilde{S}_{j}=\left(S_{j}^{a}, S_{j}^{b}, S_{j}^{c}\right)$ of alternative $A_{j}$ from the fuzzy best value $\widetilde{f}_{i}^{+}$, as well as calculate the separation $\widetilde{R}_{j}=\left(R_{j}^{a}, R_{j}^{b}, R_{j}^{c}\right)$ of alternative $A_{j}$ from the fuzzy worst value $\widetilde{f}_{i}^{-}$, as can be seen in Equations (14) and (15).

$$
\begin{aligned}
\widetilde{S}_{j} & =\sum_{i=1}^{n}\left(\widetilde{w}_{i}(\times) \widetilde{d}_{i j}\right) \\
\widetilde{R}_{j} & =\max _{i}\left(\widetilde{w}_{i}(\times) \widetilde{d}_{i j}\right)
\end{aligned}
$$

where $\widetilde{w}_{i}$ represents the fuzzy weights of each criterion.

Step 6: Calculate the worse group score values $\widetilde{Q}_{j}=\left(a_{j}, b_{j}, c_{j}\right)$, according to Equations (16)-(18) below.

$$
\begin{gathered}
\widetilde{S}^{+}=\min _{j} \widetilde{S}_{j}, S^{-, c}=\max _{j} S_{j}^{c} \\
\widetilde{R}^{+}=\min _{j} \widetilde{R}_{j}, R^{-, c}=\max _{j} R_{j}^{c} \\
\widetilde{Q}_{j}=v\left(\widetilde{S}_{j}-\widetilde{S}^{+}\right) /\left(S^{-, c}-S^{+, a}\right)(+)(1-v)\left(\widetilde{R}_{j}-\widetilde{R}^{+}\right) /\left(R^{-, c}-R^{+, a}\right)
\end{gathered}
$$

where $v$ represents the strategy of "the maximum utility", which can be varied from 0 to 1 , while $(1-v)$ represents the strategy of "the individual regret". In this paper, the value of $v$ is considered to be $0.5(v=0.5)$.

Step 7: Defuzzify triangular fuzzy number of the worse group score values $\widetilde{Q}_{j}$ into the crisp values. Rank the alternatives, sorting the values $S, R, Q$ in ascending order. Normally, the set of compromised solutions is proposed based on the ranking order of $S, R, Q$. In this study, the authors used the $Q$ ranking list [63]. The compromised solution approach (i.e., the feasible solution that is the closest to the ideal solution) to 3PL evaluation and selection is acceptable for all decision-makers because it provides a maximum "group utility of the majority" as well as the minimum "individual regret of the opponent".

\section{Result Analysis}

\subsection{Empirical Case Study}

The logistics industry in Vietnam was recently confronted with a number of obstacles, including a lack of skilled workers, unfavorable institutions and regulations, complicated administrative processes, and high logistics costs [64]. Third-party logistics (3PL) are a well-liked method to outsource logistic functions, especially for small and medium-sized businesses. The strategic selection of 3PL can help the companies to reduce costs, boost sales, and build brand identity with other competitors $[65,66]$. For performance evaluation of the 3PL sector in Vietnam based on certain influential and conflicting criteria, the authors aim to offer a fuzzy MCDM framework as well as collecting experts' judgment. In this paper, a team of 10 experts who were working in the logistics industry for the past ten years was interviewed to assess the relative importance of criteria in the 3PL outsourcing problem. More specifically, in an empirical case study, 10 potential 3PL providers (DMUs) in Vietnam are evaluated and ranked so that the most efficient one is determined.

To this end, FAHP is used to evaluate and calculate the relative significant fuzzy weight of each criterion. Figure 3 presents the decision hierarchy for choosing the logistics providers including five main criteria and 15 criteria, which are economic (logistics cost, financial stability, IT and R\&D systems, network management), service level (quality of service, reliability and delivery time, flexibility and responsiveness), environmental (environmental pollution, environmental laws, green operation), social (health and safety, voice of customer, reputation), and risk (operational risk, financial risk). In the case study of the Vietnamese logistics industry, the experts from the relevant research area were consulted to assess the effect of these criteria on the 3PL selection. 


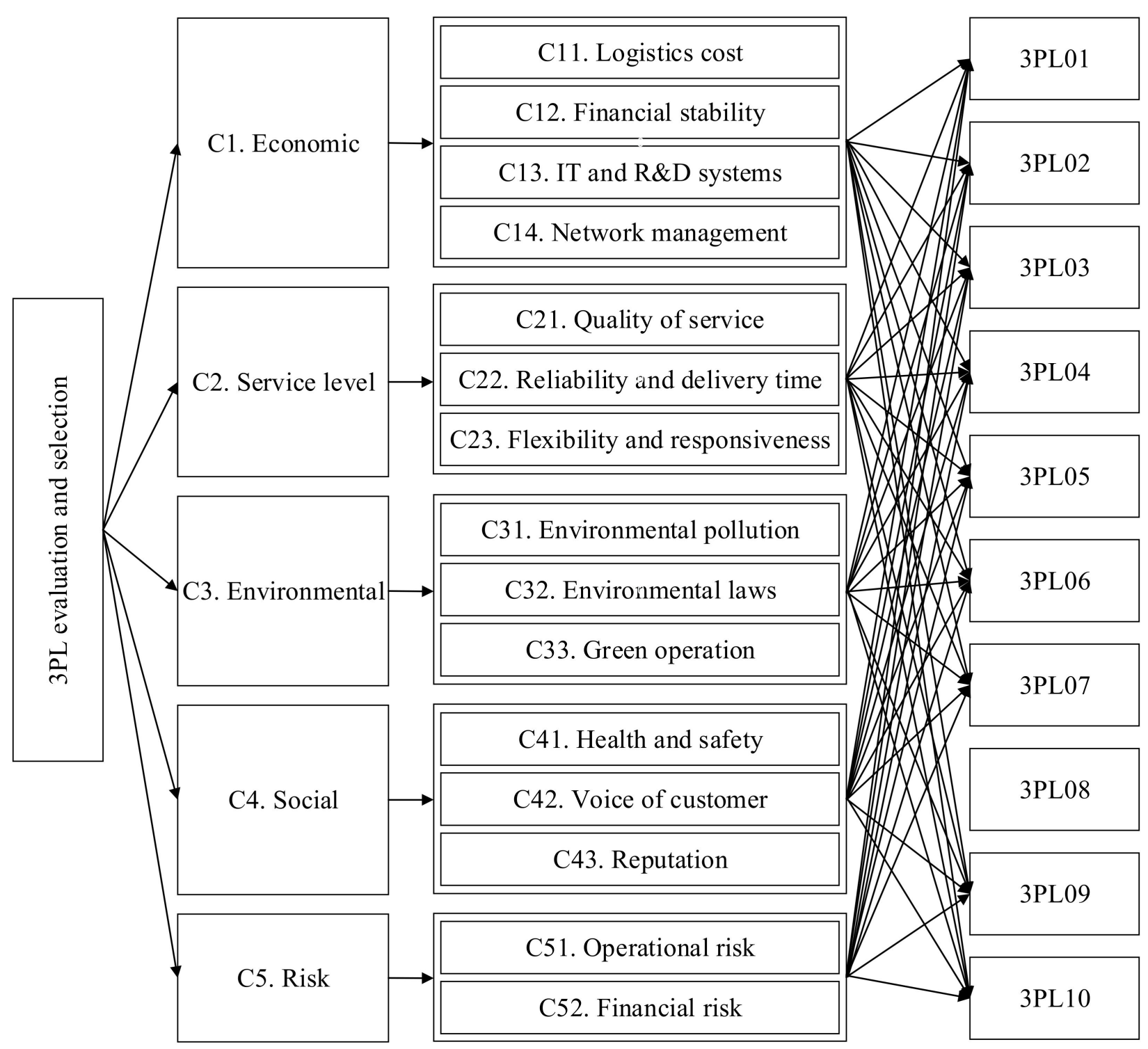

Figure 3. The decision hierarchy for choosing logistics providers.

\subsection{FAHP Result}

In order to check the consistency ratio in applying FAHP model, an example of the calculation of the five main criteria is presented in the following FAHP procedure, which are economic (C1), service level (C2), environmental (C3), social (C4), risk (C5). The initial comparison matrix and the integrated fuzzy comparison matrix of FAHP model are shown in Tables 5 and 6, respectively. 
Table 5. The initial comparison matrix of FAHP model.

\begin{tabular}{|c|c|c|c|c|c|c|c|c|c|c|c|c|c|c|c|c|c|c|}
\hline \multirow[b]{2}{*}{ 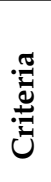 } & \multicolumn{17}{|c|}{ Linguistics Variables } & \multirow[b]{2}{*}{ 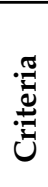 } \\
\hline & $\begin{array}{l}\hat{\circ} \\
\text { à } \\
\infty \\
\infty\end{array}$ & 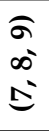 & $\begin{array}{l}\infty \\
\stackrel{0}{0} \\
0\end{array}$ & $\begin{array}{l}\mathbb{5} \\
\sigma^{\circ} \\
\omega^{\circ}\end{array}$ & $\begin{array}{l}6 \\
\text { in } \\
5\end{array}$ & $\begin{array}{l}\text { Dि } \\
\text { +5 } \\
\dot{0}\end{array}$ & 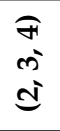 & 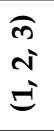 & $\begin{array}{l}\vec{I} \\
\stackrel{5}{=}\end{array}$ & $\begin{array}{l}\text { के } \\
\stackrel{5}{=}\end{array}$ & $\begin{array}{l}\text { fr } \\
\dot{n}^{\prime} \\
\stackrel{d}{ }\end{array}$ & $\begin{array}{l}\text { Dि } \\
\text { के } \\
\text { ஸ் }\end{array}$ & \begin{tabular}{l}
6 \\
in \\
\multirow{5}{*}{}
\end{tabular} & $\begin{array}{l}\text { ז } \\
\sigma^{\circ} \\
\omega^{\circ}\end{array}$ & $\begin{array}{l}\infty \\
\stackrel{\infty}{0} \\
0\end{array}$ & 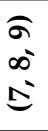 & $\begin{array}{l}\hat{\sigma} \\
a \\
\sigma^{\prime} \\
\infty\end{array}$ & \\
\hline $\mathrm{C} 1$ & & & & & & $x$ & & & & & & & & & & & & $\mathrm{C} 2$ \\
\hline $\mathrm{C} 1$ & & & & & & $x$ & & & & & & & & & & & & C3 \\
\hline $\mathrm{C} 1$ & & & & & $x$ & & & & & & & & & & & & & $\mathrm{C} 4$ \\
\hline $\mathrm{C} 1$ & & & & & & & $x$ & & & & & & & & & & & $\mathrm{C} 5$ \\
\hline $\mathrm{C} 2$ & & & & & & & $x$ & & & & & & & & & & & $\mathrm{C} 3$ \\
\hline $\mathrm{C} 2$ & & & & & & & & $x$ & & & & & & & & & & $\mathrm{C} 4$ \\
\hline $\mathrm{C} 2$ & & & & & & & & & & & $x$ & & & & & & & $\mathrm{C} 5$ \\
\hline $\mathrm{C} 3$ & & & & & & & & & & & $x$ & & & & & & & $\mathrm{C} 4$ \\
\hline $\mathrm{C} 3$ & & & & & & & & & & & & $\mathrm{x}$ & & & & & & $\mathrm{C} 5$ \\
\hline $\mathrm{C} 4$ & & & & & & & & & & & $x$ & & & & & & & $\mathrm{C} 5$ \\
\hline
\end{tabular}

Table 6. The integrated fuzzy comparison matrix of FAHP model.

\begin{tabular}{|c|c|c|c|c|c|}
\hline Criteria & $\begin{array}{l}\text { Economic } \\
\text { (C1) }\end{array}$ & $\begin{array}{c}\text { Service } \\
\text { Level (C2) }\end{array}$ & $\begin{array}{l}\text { Environmental } \\
\text { (C3) }\end{array}$ & Social (C4) & Risk (C5) \\
\hline $\begin{array}{l}\text { Economic } \\
\text { (C1) }\end{array}$ & $(1,1,1)$ & $(3,4,5)$ & $(3,4,5)$ & $(4,5,6)$ & $(2,3,4)$ \\
\hline $\begin{array}{l}\text { Service level } \\
\text { (C2) }\end{array}$ & $\begin{array}{c}(1 / 5,1 / 4 \\
1 / 3)\end{array}$ & $(1,1,1)$ & $(2,3,4)$ & $(1,2,3)$ & $\begin{array}{c}(1 / 4,1 / 3, \\
1 / 2)\end{array}$ \\
\hline $\begin{array}{l}\text { Environmental } \\
\text { (C3) }\end{array}$ & $\begin{array}{c}(1 / 5,1 / 4 \\
1 / 3)\end{array}$ & $\begin{array}{c}(1 / 4,1 / 3 \\
1 / 2)\end{array}$ & $(1,1,1)$ & $\begin{array}{c}(1 / 4,1 / 3 \\
1 / 2)\end{array}$ & $\begin{array}{c}(1 / 5,1 / 4, \\
1 / 3)\end{array}$ \\
\hline Social (C4) & $\begin{array}{c}(1 / 6,1 / 5 \\
1 / 4)\end{array}$ & $(1 / 3,1 / 2,1)$ & $(2,3,4)$ & $(1,1,1)$ & $\begin{array}{c}(1 / 4,1 / 3, \\
1 / 2)\end{array}$ \\
\hline Risk (C5) & $\begin{array}{c}(1 / 4,1 / 3 \\
1 / 2)\end{array}$ & $(2,3,4)$ & $(3,4,5)$ & $(2,3,4)$ & $(1,1,1)$ \\
\hline
\end{tabular}

In order to verify the consistency ratio $(C R)$ of the performance rating score, the linguistics terms (triangular fuzzy number) are transferred to the crisp value using pessimistic value (lower bound) and optimistic value (upper bound) values of the fuzzy comparison matrix $[67,68]$. The non-fuzzy comparison matrix of the main criteria is presented in Table 7.

Table 7. The non-fuzzy comparison matrix of FAHP model.

\begin{tabular}{cccccc}
\hline Criteria & Economic (C1) & $\begin{array}{c}\text { Service Level } \\
\text { (C2) }\end{array}$ & $\begin{array}{c}\text { Environmental } \\
\text { (C3) }\end{array}$ & Social (C4) & $\begin{array}{c}\text { Risk } \\
\text { (C5) }\end{array}$ \\
\hline Economic (C1) & 1 & 3.8730 & 3.8730 & 4.8990 & 2.8284 \\
Service level (C2) & 0.2582 & 1 & 2.8284 & 1.7321 & 0.3536 \\
Environmental (C3) & 0.2582 & 0.3536 & 1 & 0.3536 & 0.2582 \\
Social (C4) & 0.2041 & 0.5774 & 2.8284 & 1 & 0.3536 \\
Risk (C5) & 0.3536 & 2.8284 & 3.8730 & 2.8284 & 1 \\
\hline Total & 2.0741 & 8.6323 & 14.4028 & 10.8130 & 4.7937 \\
\hline
\end{tabular}

In order to get the priority vector of the five main criteria of FAHP model, the normalized pairwise comparison matrix is computed by dividing each number in a column of the matrix by its column sum. Then, the priority vector is identified by averaging the row entries in the normalized matrix, as can be seen in Table 8 . 
Table 8. The normalized comparison matrix of FAHP model.

\begin{tabular}{ccccccc}
\hline Criteria & $\begin{array}{c}\text { Economic } \\
\text { (C1) }\end{array}$ & $\begin{array}{c}\text { Service } \\
\text { Level (C2) }\end{array}$ & $\begin{array}{c}\text { Environmental } \\
\text { (C3) }\end{array}$ & Social (C4) & Risk (C5) & $\begin{array}{c}\text { Priority } \\
\text { Vector }\end{array}$ \\
\hline Economic (C1) & 0.4821 & 0.4487 & 0.2689 & 0.4531 & 0.5900 & 0.4486 \\
Service level (C2) & 0.1245 & 0.1158 & 0.1964 & 0.1602 & 0.0738 & 0.1341 \\
Environmental (C3) & 0.1245 & 0.0410 & 0.0694 & 0.0327 & 0.0539 & 0.0643 \\
Social (C4) & 0.0984 & 0.0669 & 0.1964 & 0.0925 & 0.0738 & 0.1056 \\
Risk (C5) & 0.1705 & 0.1705 & 0.1705 & 0.1705 & 0.1705 & 0.2474 \\
\hline Sum & 1 & 1 & 1 & 1 & 1 & 1 \\
\hline
\end{tabular}

The largest eigenvector $\left(\lambda_{\max }\right)$ is computed to determine the consistency index $(C I)$, the random index $(R I)$, and the consistency ratio $(C R)$, as below.

$$
\begin{aligned}
& {\left[\begin{array}{lllll}
0.4821 & 0.4487 & 0.2689 & 0.4531 & 0.5900 \\
0.1245 & 0.1158 & 0.1964 & 0.1602 & 0.0738 \\
0.1245 & 0.0410 & 0.0694 & 0.0327 & 0.0539 \\
0.0984 & 0.0669 & 0.1964 & 0.0925 & 0.0738 \\
0.1705 & 0.1705 & 0.1705 & 0.1705 & 0.1705
\end{array}\right] \times\left[\begin{array}{c}
0.4486 \\
0.1341 \\
0.0643 \\
0.10561 \\
0.2474
\end{array}\right]=\left[\begin{array}{c}
2.4341 \\
0.7021 \\
0.3287 \\
0.5439 \\
1.3330
\end{array}\right]} \\
& {\left[\begin{array}{l}
2.4341 \\
0.7021 \\
0.3287 \\
0.5439 \\
1.3330
\end{array}\right] /\left[\begin{array}{c}
0.4486 \\
0.1341 \\
0.0643 \\
0.10561 \\
0.2474
\end{array}\right]=\left[\begin{array}{l}
5.4266 \\
5.2348 \\
5.1137 \\
5.1514 \\
5.3872
\end{array}\right]}
\end{aligned}
$$

There are five main criteria. Therefore, we get $n=5$. Consequently, $\lambda_{\max }$ and $C I$ are computed as below.

$$
\begin{gathered}
\lambda_{\max }=\frac{5.4266+5.2348+5.1137+5.1514+5.3872}{5}=5.2627 \\
C I=\frac{\lambda_{\max }-n}{n-1}=\frac{5.2627-5}{5-1}=0.0657
\end{gathered}
$$

such that $n=5$, we get $R I=1.12$, and the consistency ratio $(C R)$ is computed as below.

$$
C R=\frac{C I}{R I}=\frac{0.0657}{1.12}=0.0586
$$

Based on the result, $C R=0.0586<0.1$. Hence, the pairwise comparison matrix is consistent, and the result of the FAHP model is satisfactory. Then, other criteria are computed using the same procedure. The integrated fuzzy comparison matrix of all criteria is shown in Table A1 (Appendix A).

In this paper, the rating of each criterion for alternatives is described by the linguistic terms in triangular fuzzy numbers including pessimistic, most likely, and optimistic value. The concept of the fuzzy geometric mean is applied to calculate the relative significant fuzzy weights of all criteria, as can be seen in Table 9. From the results, the fuzzy weight of criteria logistics cost (C11) has the lowest weight (pessimistic value) at 0.0373 , the middle weight (most likely value) of 0.0770 , and the highest weight (optimistic value) of 0.1571 . As the same concept, the fuzzy weight of criteria financial stability has the pessimistic weight at 0.0364 , the most likely weight of 0.0736 , and the most optimistic weight of 0.1449 . Other criteria have the same explanation. These fuzzy preference weights will be used in FVIKOR model for ranking alternatives in the final stage.

Figure 4 shows the relatively significant level of criteria of the FAHP model. As can be seen, reliability and delivery time (C22), voice of customer (C42), logistics cost (C11), network management (C14), and quality of service (C21) have the most significant level, at $0.0928,0.0914,0.0905,0.0899$, and 0.0892 , respectively. Among the criteria, the results recommend that in experts' evaluation, reliability and delivery time (as a service level criterion) is a more impactful criterion than economic factors such as logistics cost and 
network management. Quality of service was also ranked high at the fifth. To elaborate, 3PL services, when optimized, can be beneficial for both carriers and shippers [69]. For instance, carriers can increase billable minutes by increasing network efficiency and optimize networks across multiple systems to roll out advanced and higher-margin services for customers. During COVID-19, more efficient shipping, high inventory turnover, and inventory staged in forwarding locations near consumers. Voice of customer (as of social criteria) is also positioned second in the expert ranking. This expounds that gaining information from customers provides a unique advantage that allows any business to best align value proposition, products, services, and delivery infrastructure to meet customer satisfaction [30]. IT and R\&D systems received the sixth rank since technology drives the modern 3PL in recent times. To keep up with customer demand, modern 3PLs have evolved their services and integrated technology. Similarly, shippers are turning to technology-enabled 3PL providers to improve overall productivity and results. An end-to-end supply chain approach is provided by the convergence of technology and logistics.

Following the financial stability criterion (ranked seventh), it is exceptional that environmental laws and environmental pollution were also recommended to receive considerable attention when choosing 3PLs, according to experts' judgments. This also indicates that environmental drivers were noteworthy by the practitioners as being one of the three pillars of sustainable development in this era [26]. Ecological sustainability has fast become an expected component of 3PL service offerings, necessitating the adaptation of operations and policies from a green perspective to minimize negative environmental externalities. However, for surviving, most businesses, especially in developing countries such as Vietnam, are focusing solely on manufacturing and economic sectors, and thus, little attention has been paid to sustainable development. Hence, it is imperative that 3PL companies commit themselves to environmental sustainability goals, especially to take in preparation for the bounce back post COVID-19 pandemic.

\subsection{FVIKOR Result}

In FVIKOR model, the rating of each alternative and the weight of each criterion are described by triangular linguistics terms (i.e., the fuzzy weights of criteria are obtained from FAHP model). The main concept of FVIKOR model is to rank multiple alternatives based on the compromise solution approach that provides a maximum "group utility of the majority" as well as the minimum "individual regret of the opponent" (i.e., the smaller the value of worse group score $Q_{j}$, the better the alternative is). According to the process of FVIKOR, the top three potential third-party logistics (3PL) providers are shown in Table 10 and Figure 5, which are 3PL01, 3PL08, and 3PL02 ranked the first, second, and third with the worse group score of each alternative of $0.0375,0.0425$, and 0.0580 , respectively. Note that the aggregated fuzzy decision matrix, and fuzzy best value and fuzzy worst value of FVIKOR model are presented in Tables A2 and A3 (Appendix A). 
Table 9. The relative significant fuzzy weights of each criterion of FAHP model.

\begin{tabular}{|c|c|c|c|c|c|c|c|}
\hline Criteria & \multicolumn{3}{|c|}{ Fuzzy Geometric Mean } & \multicolumn{3}{|c|}{ Fuzzy Weights } & \multirow{2}{*}{$\begin{array}{c}\text { Normalize } \\
0.0778\end{array}$} \\
\hline C11. Logistics cost & 0.7974 & 1.1725 & 1.6943 & 0.0373 & 0.0770 & 0.1571 & \\
\hline C12. Financial stability & 0.7791 & 1.1195 & 1.5630 & 0.0364 & 0.0736 & 0.1449 & 0.0731 \\
\hline C13. IT and R\&D systems & 0.7617 & 1.1156 & 1.5952 & 0.0356 & 0.0733 & 0.1479 & 0.0736 \\
\hline $\begin{array}{l}\text { C14. Network } \\
\text { management }\end{array}$ & 0.7894 & 1.1672 & 1.6843 & 0.0369 & 0.0767 & 0.1561 & 0.0773 \\
\hline C21. Quality of service & 0.8432 & 1.1782 & 1.6270 & 0.0394 & 0.0774 & 0.1508 & 0.0767 \\
\hline $\begin{array}{l}\text { C22. Reliability and } \\
\text { delivery time }\end{array}$ & 0.8692 & 1.2248 & 1.6975 & 0.0406 & 0.0805 & 0.1574 & 0.0798 \\
\hline $\begin{array}{l}\text { C23. Flexibility and } \\
\text { responsiveness }\end{array}$ & 0.5631 & 0.8017 & 1.1737 & 0.0263 & 0.0527 & 0.1088 & 0.0538 \\
\hline $\begin{array}{l}\text { C31. Environmental } \\
\text { pollution }\end{array}$ & 0.7479 & 1.0453 & 1.4157 & 0.0350 & 0.0687 & 0.1312 & 0.0673 \\
\hline C32. Environmental laws & 0.7817 & 1.0834 & 1.4583 & 0.0365 & 0.0712 & 0.1352 & 0.0696 \\
\hline C33. Green operation & 0.6168 & 0.8484 & 1.2055 & 0.0288 & 0.0557 & 0.1118 & 0.0563 \\
\hline C41. Health and safety & 0.5679 & 0.7634 & 1.0755 & 0.0265 & 0.0502 & 0.0997 & 0.0506 \\
\hline C42. Voice of customer & 0.8536 & 1.2059 & 1.6729 & 0.0399 & 0.0792 & 0.1551 & 0.0786 \\
\hline C43. Reputation & 0.5952 & 0.8176 & 1.1594 & 0.0278 & 0.0537 & 0.1075 & 0.0542 \\
\hline C51. Operational risk & 0.5701 & 0.7798 & 1.1143 & 0.0266 & 0.0512 & 0.1033 & 0.0519 \\
\hline C52. Financial risk & 0.6503 & 0.8968 & 1.2602 & 0.0304 & 0.0589 & 0.1168 & 0.0591 \\
\hline
\end{tabular}

\section{Significant Level of Criteria}

C22. Reliability and delivery time C42. Voice of customer

C11. Logistics cost

C14. Network management

C21. Quality of service

C13. IT and R\&D systems

C12. Financial stability

C32. Environmental laws

C31. Environmental pollution

C52. Financial risk

C33. Green operation

C43. Reputation

C23. Flexibility and responsiveness

C51. Operational risk

C41. Health and safety

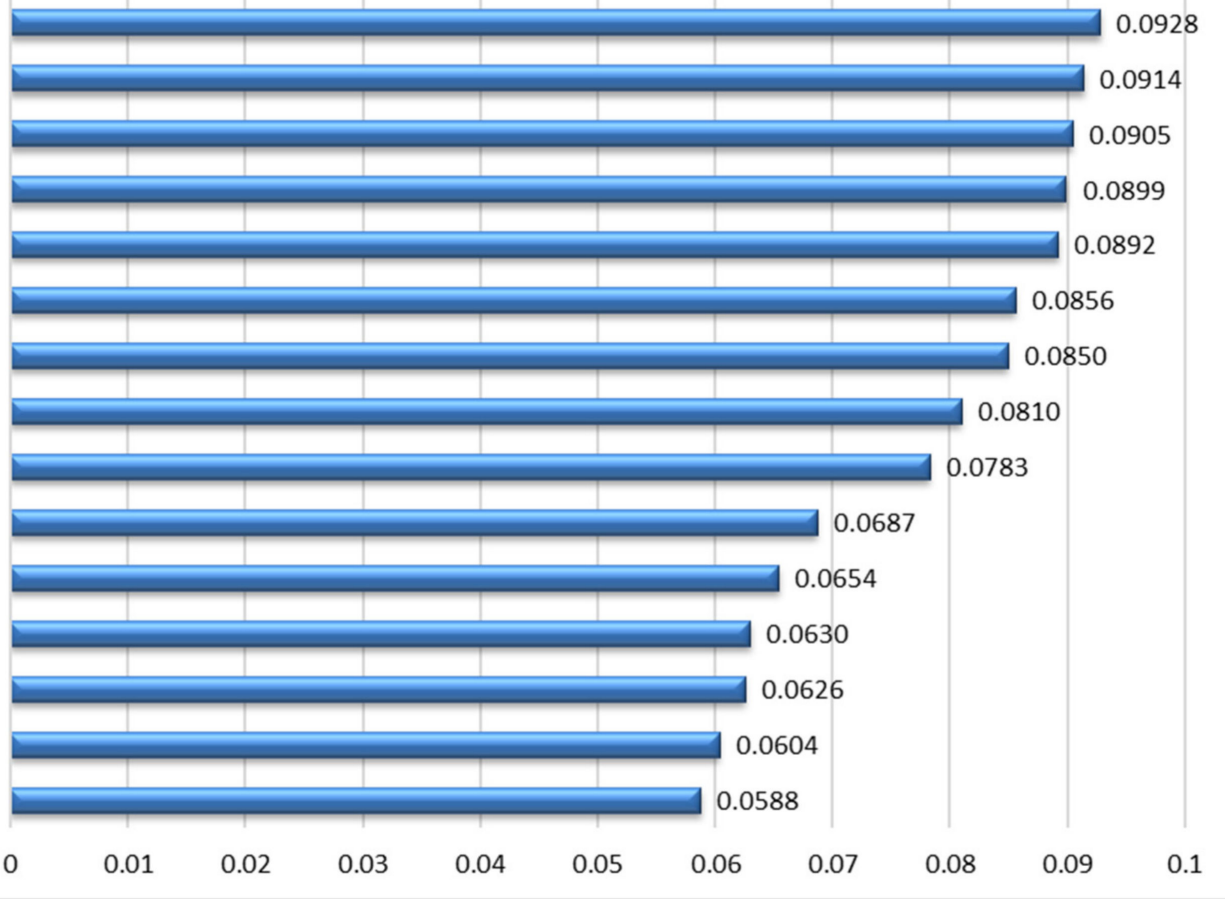

Figure 4. The relative significant level of criteria of FAHP model. 
Table 10. The worse group score of FVIKOR model.

\begin{tabular}{cccc}
\hline Alternatives & Crisp $S_{j}$ & Crisp $\boldsymbol{R}_{j}$ & Crisp $Q_{j}$ \\
\hline 3PL01 & 0.2822 & 0.0610 & 0.0375 \\
3PL02 & 0.4895 & 0.0503 & 0.0580 \\
3PL03 & 0.5242 & 0.0510 & 0.0693 \\
3PL04 & 0.7542 & 0.0696 & 0.1914 \\
3PL05 & 0.4950 & 0.0753 & 0.1409 \\
3PL06 & 0.8191 & 0.0768 & 0.2321 \\
3PL07 & 0.6296 & 0.0695 & 0.1578 \\
3PL08 & 0.3932 & 0.0534 & 0.0425 \\
3PL09 & 0.7494 & 0.0686 & 7 \\
3PL10 & 0.5342 & 0.0495 & 0.1869 \\
\end{tabular}

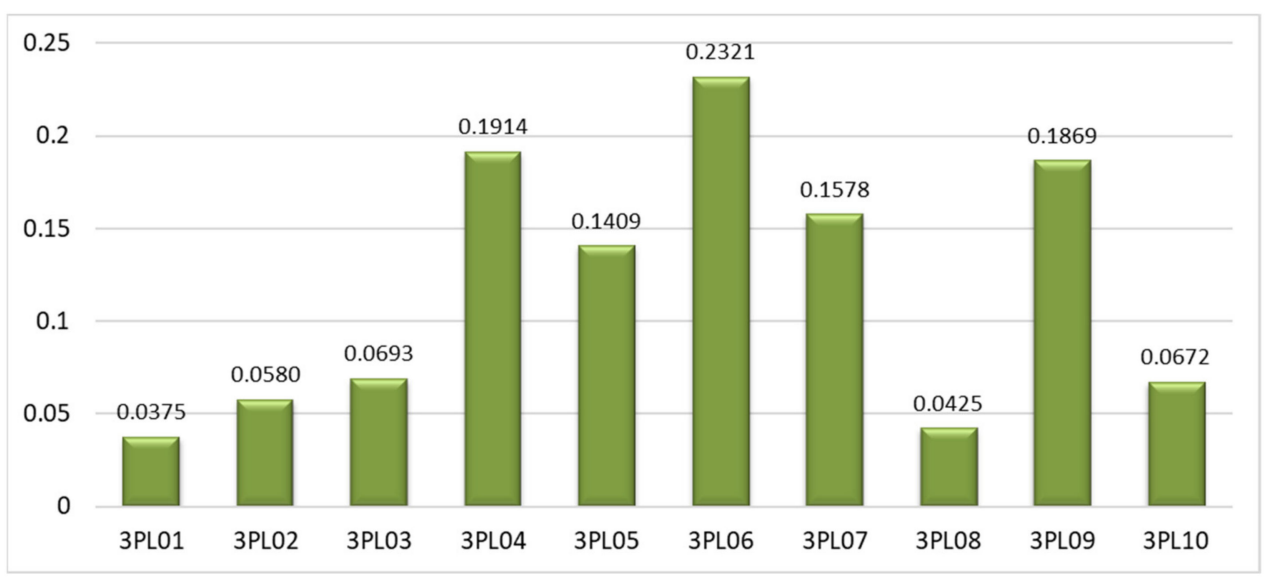

Figure 5. Alternatives ranking of FVIKOR model.

\section{Discussion and Conclusions}

Logistics outsourcing to 3PL is a critical component for today's businesses to lead supply chains toward sustainability. As the world becomes increasingly globalized, and consumer demand for fast and free shipping keeps climbing, so does the demand for 3PL services. Efficient and momentous decisions on outsourcing are vital to the performance of businesses in today's competitive market. A complete transformation in business operations and logistical procedures caused by the COVID-19 pandemic indicates that processes have become more dynamic than before so that companies are being placed in a position to choose between the most critical tasks. The pandemic also reveals for many organizations that they have a lack of visibility in the further reaches of their supply chain [70]. Thus, one of the services that offers many potentials is outsourcing to 3PL providers, which must be placed at the forefront of any business with supply chain management. A 3PL having advanced technology along with an efficient and expert workforce will enhance businesses with their expertise and operational efficiency. In today's context, it must be mentioned that green factors and policies have become increasingly important for businesses as public awareness of their environmental impact has grown. The environmental performance of a corporation is influenced by the environmental performance and image of its suppliers, in addition to the company's internal environmental efforts.

Hence, this paper proposes a hybrid multi-criteria optimization model which can be employed for solving the logistics outsourcing problems to a third party in this era. The research procedure consists of two stages. First, FAHP is used to evaluate and calculate the relative significant fuzzy weight of each criterion. Knowing the well-developed status of 3PL evaluation and selection, the authors define the list of criteria including economic, service level, environmental, social, and risk as dominant decision-making factors in 3PL 
selection. Consequently, the list of 15 criteria is defined including economic (logistics cost, financial stability, IT and R\&D systems, network management), service level (quality of service, reliability and delivery time, flexibility and responsiveness), environmental (environmental pollution, environmental laws, green operation), social (health and safety, voice of customer, reputation), and risk (operational risk, financial risk). In the second stage, FVIKOR is developed to rank the alternatives. The use of linguistic terms through the whole evaluation process can resolve the fuzzy and uncertain decision-making problem in nature [71]. Results from the AHP indicate that reliability and delivery time, voice of customer, logistics cost, network management, and quality of service are the most impactful factors when choosing providers in the Vietnam 3PL market. From the final ranking by FVIKOR, 3PL01 was identified as the most efficient logistics provider with a score of 0.0375 .

Therefore, the contributions of the papers can be summarized as follows. First, this paper proposed a hybrid MCDM model by combining FAHP and FVIKOR models for the evaluation and selection of logistics providers based on multiple factors in economic, environmental, and social aspects. Second, the results of a case study of 10 potential logistics companies in Vietnam provide managerial insights into the logistics industry in Vietnam. Third, the authors expect that the results of the paper will reflect the current picture of Vietnamese logistics, especially in the COVID-19 pandemic. Therefore, this paper can be used as a useful guideline for government, investors, and policymakers in selecting and investing in the logistics industry toward sustainability.

It is proven through many applications of MCDM methods in several types of industries. The capabilities of these methods to be tailor-fitted according to the requirements of certain industries make them more applicable if may not all, to many kinds of industries. Future studies should consider new assessment factors with respect to the post-COVID-19 pandemic that can impact the process of evaluation and selection of logistics providers to enhance the robust results. Besides, other MCDM models, such as DEA, TOPSIS, PROMETHEE II, COPRAS, SWARA, etc., should be combined for ranking alternatives [72,73], and the accuracy and reliability of these rankings should be measured using a reference for ranking similarity coefficients (i.e., weighted Spearman's rank correlation coefficient, rank similarity coefficient) $[28,74]$.

Author Contributions: Conceptualization, C.-M.L. and T.-T.D.; data curation, T.-T.D.; formal analysis, N.-A.-T.N.; funding acquisition, C.-N.W.; investigation, N.-A.-T.N.; methodology, T.-T.D.; project administration, C.-M.L.; software, T.-T.D.; validation, C.-N.W.; writing-original draft, T.-T.D. and N.-A.-T.N.; writing-review and editing, C.-N.W. and C.-M.L. All authors have read and agreed to the published version of the manuscript.

Funding: This research was partly supported by the National Kaohsiung University of Science and Technology and project number MOST 109-2622-E-992-026 from the Ministry of Sciences and Technology in Taiwan.

Institutional Review Board Statement: Not applicable.

Informed Consent Statement: Not applicable.

Data Availability Statement: Not applicable.

Acknowledgments: The authors appreciate the support from the National Kaohsiung University of Science and Technology, Taiwan; Ministry of Sciences and Technology; Taiwan; and Shanghai General Hospital, China.

Conflicts of Interest: The authors declare no conflict of interest. 


\section{Appendix A}

Table A1. The aggregated fuzzy comparison matrix of FAHP model.

\begin{tabular}{|c|c|c|c|c|c|c|c|c|c|c|c|c|}
\hline Criteria & & $\mathrm{C} 11$ & & & $\mathrm{C} 12$ & & & $\mathrm{C} 13$ & & & C14 & \\
\hline C11. Logistics cost & 1.00 & 1.00 & 1.00 & 1.10 & 1.71 & 2.48 & 0.75 & 1.07 & 1.57 & 0.52 & 0.78 & 1.25 \\
\hline C12. Financial stability & 0.40 & 0.58 & 0.91 & 1.00 & 1.00 & 1.00 & 0.80 & 1.20 & 1.71 & 0.75 & 1.15 & 1.66 \\
\hline C13. IT and R\&D systems & 0.64 & 0.93 & 1.34 & 0.58 & 0.84 & 1.25 & 1.00 & 1.00 & 1.00 & 1.27 & 1.99 & 2.78 \\
\hline C21. Quality of service & 0.50 & 0.73 & 1.12 & 0.58 & 0.84 & 1.25 & 0.51 & 0.75 & 1.16 & 0.29 & 0.41 & 0.65 \\
\hline $\begin{array}{l}\text { C22. Reliability and } \\
\text { delivery time }\end{array}$ & 0.40 & 0.58 & 0.91 & 0.51 & 0.70 & 1.04 & 0.41 & 0.60 & 0.94 & 0.41 & 0.60 & 0.94 \\
\hline $\begin{array}{l}\text { C31. Environmental } \\
\text { pollution }\end{array}$ & 0.50 & 0.73 & 1.12 & 0.58 & 0.84 & 1.25 & 0.92 & 1.43 & 2.15 & 1.76 & 2.65 & 3.48 \\
\hline C32. Environmental laws & 0.90 & 1.37 & 2.01 & 0.79 & 1.06 & 1.37 & 0.45 & 0.62 & 0.89 & 0.51 & 0.75 & 1.16 \\
\hline C33. Green operation & 0.50 & 0.73 & 1.12 & 0.83 & 1.25 & 1.83 & 0.58 & 0.87 & 1.37 & 0.51 & 0.75 & 1.16 \\
\hline C41. Health and safety & 0.90 & 1.37 & 2.01 & 0.36 & 0.47 & 0.71 & 0.50 & 0.66 & 0.89 & 0.51 & 0.75 & 1.16 \\
\hline C42. Voice of customer & 0.50 & 0.73 & 1.12 & 0.83 & 1.25 & 1.83 & 0.92 & 1.43 & 2.15 & 0.92 & 1.43 & 2.15 \\
\hline C43. Reputation & 0.50 & 0.73 & 1.12 & 0.83 & 1.25 & 1.83 & 0.92 & 1.43 & 2.15 & 0.51 & 0.75 & 1.16 \\
\hline C51. Operational risk & 0.50 & 0.73 & 1.12 & 0.47 & 0.67 & 1.01 & 0.92 & 1.43 & 2.15 & 0.51 & 0.75 & 1.16 \\
\hline Criteria & & $\mathrm{C} 21$ & & & $\mathrm{C} 22$ & & & $\mathrm{C} 23$ & & & C31 & \\
\hline C11. Logistics cost & 0.90 & 1.37 & 2.01 & 1.10 & 1.71 & 2.48 & 1.10 & 1.71 & 2.48 & 0.90 & 1.37 & 2.01 \\
\hline C12. Financial stability & 0.80 & 1.20 & 1.71 & 0.96 & 1.43 & 1.97 & 0.96 & 1.43 & 1.97 & 0.80 & 1.20 & 1.71 \\
\hline C13. IT and R\&D systems & 0.86 & 1.34 & 1.97 & 1.06 & 1.66 & 2.42 & 1.06 & 1.66 & 2.42 & 0.46 & 0.70 & 1.08 \\
\hline $\begin{array}{l}\text { C14. Network } \\
\text { management }\end{array}$ & 1.53 & 2.42 & 3.42 & 1.06 & 1.66 & 2.42 & 1.06 & 1.66 & 2.42 & 0.29 & 0.38 & 0.57 \\
\hline C21. Quality of service & 1.00 & 1.00 & 1.00 & 0.90 & 1.37 & 2.01 & 0.93 & 1.41 & 2.06 & 2.53 & 3.40 & 4.21 \\
\hline $\begin{array}{l}\text { C22. Reliability and } \\
\text { delivery time }\end{array}$ & 0.50 & 0.73 & 1.12 & 1.00 & 1.00 & 1.00 & 1.53 & 2.13 & 2.64 & 0.48 & 0.70 & 1.04 \\
\hline $\begin{array}{l}\text { C23. Flexibility and } \\
\text { responsiveness }\end{array}$ & 0.49 & 0.71 & 1.07 & 0.38 & 0.47 & 0.65 & 1.00 & 1.00 & 1.00 & 1.53 & 2.42 & 3.42 \\
\hline $\begin{array}{l}\text { C31. Environmental } \\
\text { pollution }\end{array}$ & 0.24 & 0.29 & 0.40 & 0.96 & 1.43 & 2.07 & 0.29 & 0.41 & 0.65 & 1.00 & 1.00 & 1.00 \\
\hline C32. Environmental laws & 0.24 & 0.29 & 0.40 & 0.96 & 1.43 & 2.07 & 1.76 & 2.65 & 3.48 & 0.51 & 0.65 & 0.93 \\
\hline
\end{tabular}


Table A1. Cont.

\begin{tabular}{|c|c|c|c|c|c|c|c|c|c|c|c|c|}
\hline C33. Green operation & 0.50 & 0.73 & 1.12 & 0.83 & 1.25 & 1.83 & 0.58 & 0.87 & 1.37 & 0.51 & 0.75 & 1.16 \\
\hline C41. Health and safety & 0.90 & 1.37 & 2.01 & 0.36 & 0.47 & 0.71 & 0.50 & 0.66 & 0.89 & 0.51 & 0.75 & 1.16 \\
\hline C42. Voice of customer & 0.50 & 0.73 & 1.12 & 0.83 & 1.25 & 1.83 & 0.92 & 1.43 & 2.15 & 0.92 & 1.43 & 2.15 \\
\hline C43. Reputation & 0.50 & 0.73 & 1.12 & 0.83 & 1.25 & 1.83 & 0.92 & 1.43 & 2.15 & 0.51 & 0.75 & 1.16 \\
\hline C51. Operational risk & 0.50 & 0.73 & 1.12 & 0.47 & 0.67 & 1.01 & 0.92 & 1.43 & 2.15 & 0.51 & 0.75 & 1.16 \\
\hline C52. Financial risk & 0.90 & 1.37 & 2.01 & 0.47 & 0.67 & 1.01 & 0.51 & 0.75 & 1.16 & 0.29 & 0.41 & 0.65 \\
\hline Criteria & & $\mathrm{C} 21$ & & & $\mathrm{C} 22$ & & & $\mathrm{C} 23$ & & & C31 & \\
\hline C11. Logistics cost & 0.90 & 1.37 & 2.01 & 1.10 & 1.71 & 2.48 & 1.10 & 1.71 & 2.48 & 0.90 & 1.37 & 2.01 \\
\hline C12. Financial stability & 0.80 & 1.20 & 1.71 & 0.96 & 1.43 & 1.97 & 0.96 & 1.43 & 1.97 & 0.80 & 1.20 & 1.71 \\
\hline C13. IT and R\&D systems & 0.86 & 1.34 & 1.97 & 1.06 & 1.66 & 2.42 & 1.06 & 1.66 & 2.42 & 0.46 & 0.70 & 1.08 \\
\hline $\begin{array}{l}\text { C14. Network } \\
\text { management }\end{array}$ & 1.53 & 2.42 & 3.42 & 1.06 & 1.66 & 2.42 & 1.06 & 1.66 & 2.42 & 0.29 & 0.38 & 0.57 \\
\hline C21. Quality of service & 1.00 & 1.00 & 1.00 & 0.90 & 1.37 & 2.01 & 0.93 & 1.41 & 2.06 & 2.53 & 3.40 & 4.21 \\
\hline $\begin{array}{l}\text { C22. Reliability and } \\
\text { delivery time }\end{array}$ & 0.50 & 0.73 & 1.12 & 1.00 & 1.00 & 1.00 & 1.53 & 2.13 & 2.64 & 0.48 & 0.70 & 1.04 \\
\hline $\begin{array}{l}\text { C23. Flexibility and } \\
\text { responsiveness }\end{array}$ & 0.49 & 0.71 & 1.07 & 0.38 & 0.47 & 0.65 & 1.00 & 1.00 & 1.00 & 1.53 & 2.42 & 3.42 \\
\hline $\begin{array}{l}\text { C31. Environmental } \\
\text { pollution }\end{array}$ & 0.24 & 0.29 & 0.40 & 0.96 & 1.43 & 2.07 & 0.29 & 0.41 & 0.65 & 1.00 & 1.00 & 1.00 \\
\hline C33. Green operation & 0.49 & 0.66 & 0.96 & 0.31 & 0.41 & 0.60 & 0.92 & 1.43 & 2.15 & 0.92 & 1.25 & 1.73 \\
\hline C41. Health and safety & 0.49 & 0.66 & 0.96 & 0.31 & 0.41 & 0.60 & 0.51 & 0.75 & 1.16 & 0.51 & 0.65 & 0.93 \\
\hline C42. Voice of customer & 1.15 & 1.73 & 2.41 & 0.34 & 0.47 & 0.73 & 0.51 & 0.75 & 1.16 & 0.92 & 1.25 & 1.73 \\
\hline C43. Reputation & 0.49 & 0.66 & 0.96 & 0.41 & 0.52 & 0.68 & 0.51 & 0.75 & 1.16 & 0.29 & 0.39 & 0.58 \\
\hline C51. Operational risk & 0.49 & 0.66 & 0.96 & 0.22 & 0.29 & 0.42 & 0.92 & 1.43 & 2.15 & 0.51 & 0.65 & 0.93 \\
\hline C52. Financial risk & 0.81 & 1.10 & 1.46 & 0.33 & 0.45 & 0.68 & 0.92 & 1.43 & 2.15 & 0.92 & 1.25 & 1.73 \\
\hline Criteria & & $\mathrm{C} 32$ & & & $\mathrm{C} 33$ & & & C41 & & & C42 & \\
\hline C11. Logistics cost & 0.50 & 0.73 & 1.12 & 0.90 & 1.37 & 2.01 & 0.50 & 0.73 & 1.12 & 0.90 & 1.37 & 2.01 \\
\hline C12. Financial stability & 0.73 & 0.94 & 1.27 & 0.55 & 0.80 & 1.21 & 1.41 & 2.13 & 2.78 & 0.55 & 0.80 & 1.21 \\
\hline C13. IT and R\&D systems & 1.13 & 1.62 & 2.23 & 0.73 & 1.15 & 1.71 & 1.13 & 1.52 & 2.00 & 0.46 & 0.70 & 1.08 \\
\hline $\begin{array}{l}\text { C14. Network } \\
\text { management }\end{array}$ & 0.86 & 1.34 & 1.97 & 0.86 & 1.34 & 1.97 & 0.86 & 1.34 & 1.97 & 0.46 & 0.70 & 1.08 \\
\hline C21. Quality of service & 2.53 & 3.40 & 4.21 & 1.04 & 1.52 & 2.06 & 1.04 & 1.52 & 2.06 & 0.42 & 0.58 & 0.87 \\
\hline $\begin{array}{l}\text { C22. Reliability and } \\
\text { delivery time }\end{array}$ & 0.48 & 0.70 & 1.04 & 1.66 & 2.43 & 3.26 & 1.66 & 2.43 & 3.26 & 1.37 & 2.13 & 2.94 \\
\hline
\end{tabular}


Table A1. Cont.

\begin{tabular}{|c|c|c|c|c|c|c|c|c|c|c|c|c|}
\hline $\begin{array}{l}\mathrm{C} 23 . \text { Flexibility and } \\
\text { responsiveness }\end{array}$ & 0.29 & 0.38 & 0.57 & 0.46 & 0.70 & 1.08 & 0.86 & 1.34 & 1.97 & 0.86 & 1.34 & 1.97 \\
\hline $\begin{array}{l}\text { C31. Environmental } \\
\text { pollution }\end{array}$ & 1.07 & 1.53 & 1.97 & 0.58 & 0.80 & 1.08 & 1.07 & 1.53 & 1.97 & 0.58 & 0.80 & 1.08 \\
\hline C32. Environmental laws & 1.00 & 1.00 & 1.00 & 1.07 & 1.53 & 1.97 & 0.58 & 0.80 & 1.08 & 1.07 & 1.53 & 1.97 \\
\hline C33. Green operation & 0.51 & 0.65 & 0.93 & 1.00 & 1.00 & 1.00 & 0.75 & 1.07 & 1.49 & 0.46 & 0.61 & 0.87 \\
\hline C41. Health and safety & 0.92 & 1.25 & 1.73 & 0.67 & 0.93 & 1.34 & 1.00 & 1.00 & 1.00 & 0.40 & 0.51 & 0.73 \\
\hline C42. Voice of customer & 0.51 & 0.65 & 0.93 & 1.15 & 1.64 & 2.15 & 1.37 & 1.97 & 2.48 & 1.00 & 1.00 & 1.00 \\
\hline C43. Reputation & 0.40 & 0.55 & 0.81 & 0.67 & 0.93 & 1.34 & 1.15 & 1.64 & 2.15 & 0.67 & 0.93 & 1.34 \\
\hline C51. Operational risk & 0.40 & 0.55 & 0.81 & 0.67 & 0.93 & 1.34 & 0.67 & 0.93 & 1.34 & 0.40 & 0.55 & 0.81 \\
\hline C52. Financial risk & 0.67 & 0.93 & 1.34 & 1.15 & 1.64 & 2.15 & 0.67 & 0.93 & 1.34 & 0.27 & 0.35 & 0.51 \\
\hline Criteria & & $\mathrm{C} 43$ & & & $\mathrm{C} 51$ & & & C52 & & & & \\
\hline C11. Logistics cost & 0.90 & 1.37 & 2.01 & 0.90 & 1.37 & 2.01 & 0.50 & 0.73 & 1.12 & & & \\
\hline C12. Financial stability & 0.55 & 0.80 & 1.21 & 0.99 & 1.49 & 2.11 & 0.99 & 1.49 & 2.11 & & & \\
\hline C13. IT and R\&D systems & 0.46 & 0.70 & 1.08 & 0.46 & 0.70 & 1.08 & 0.86 & 1.34 & 1.97 & & & \\
\hline $\begin{array}{l}\text { C14. Network } \\
\text { management }\end{array}$ & 0.86 & 1.34 & 1.97 & 0.86 & 1.34 & 1.97 & 1.53 & 2.42 & 3.42 & & & \\
\hline C21. Quality of service & 1.04 & 1.52 & 2.06 & 1.04 & 1.52 & 2.06 & 0.68 & 0.91 & 1.23 & & & \\
\hline $\begin{array}{l}\text { C23. Flexibility and } \\
\text { responsiveness }\end{array}$ & 0.86 & 1.34 & 1.97 & 0.46 & 0.70 & 1.08 & 0.46 & 0.70 & 1.08 & & & \\
\hline $\begin{array}{l}\text { C31. Environmental } \\
\text { pollution }\end{array}$ & 1.71 & 2.59 & 3.42 & 1.07 & 1.53 & 1.97 & 0.58 & 0.80 & 1.08 & & & \\
\hline C32. Environmental laws & 1.23 & 1.83 & 2.48 & 1.23 & 1.83 & 2.48 & 0.75 & 1.07 & 1.49 & & & \\
\hline C33. Green operation & 0.75 & 1.07 & 1.49 & 0.75 & 1.07 & 1.49 & 0.46 & 0.61 & 0.87 & & & \\
\hline C41. Health and safety & 0.46 & 0.61 & 0.87 & 0.75 & 1.07 & 1.49 & 0.75 & 1.07 & 1.49 & & & \\
\hline C42. Voice of customer & 0.75 & 1.07 & 1.49 & 1.23 & 1.83 & 2.48 & 1.97 & 2.84 & 3.66 & & & \\
\hline C43. Reputation & 1.00 & 1.00 & 1.00 & 0.46 & 0.61 & 0.87 & 0.75 & 1.07 & 1.49 & & & \\
\hline C51. Operational risk & 1.15 & 1.64 & 2.15 & 1.00 & 1.00 & 1.00 & 0.46 & 0.61 & 0.87 & & & \\
\hline C52. Financial risk & 0.67 & 0.93 & 1.34 & 1.15 & 1.64 & 2.15 & 1.00 & 1.00 & 1.00 & & & \\
\hline
\end{tabular}


Table A2. The aggregated fuzzy decision matrix of FVIKOR model.

\begin{tabular}{|c|c|c|c|c|c|c|c|c|c|}
\hline \multirow{2}{*}{$\begin{array}{c}\text { 3PL } \\
\text { 3PL01 }\end{array}$} & \multicolumn{3}{|c|}{ Logistics Cost } & \multicolumn{3}{|c|}{ Financial Stability } & \multicolumn{3}{|c|}{ IT and R\&D Systems } \\
\hline & 6.90 & 7.90 & 8.90 & 6.10 & 7.15 & 8.20 & 6.00 & 7.15 & 8.30 \\
\hline 3PL02 & 5.40 & 6.50 & 7.60 & 4.70 & 5.75 & 6.80 & 2.90 & 4.10 & 5.30 \\
\hline 3PL03 & 3.90 & 5.00 & 6.10 & 3.70 & 4.80 & 5.90 & 2.90 & 4.25 & 5.60 \\
\hline 3PL05 & 1.40 & 2.65 & 3.90 & 1.40 & 2.65 & 3.90 & 5.90 & 7.10 & 8.30 \\
\hline 3PL06 & 5.80 & 6.95 & 8.10 & 1.30 & 2.30 & 3.30 & 1.30 & 2.30 & 3.30 \\
\hline 3PL07 & 2.70 & 3.90 & 5.10 & 2.10 & 3.40 & 4.70 & 5.00 & 6.25 & 7.50 \\
\hline 3PL08 & 5.00 & 6.10 & 7.20 & 4.90 & 6.00 & 7.10 & 5.00 & 6.10 & 7.20 \\
\hline 3PL10 & 3.90 & 5.00 & 6.10 & 3.70 & 4.80 & 5.90 & 2.90 & 4.25 & 5.60 \\
\hline 3PL & \multicolumn{3}{|c|}{ Network Management } & \multicolumn{3}{|c|}{ Quality of Service } & \multicolumn{3}{|c|}{ Reliability and Delivery Time } \\
\hline 3PL01 & 5.10 & 6.40 & 7.70 & 5.80 & 6.95 & 8.10 & 6.10 & 7.30 & 8.50 \\
\hline 3PL02 & 5.30 & 6.30 & 7.30 & 3.50 & 4.55 & 5.60 & 4.10 & 5.15 & 6.20 \\
\hline 3PL03 & 4.10 & 5.15 & 6.20 & 4.00 & 5.10 & 6.20 & 4.70 & 5.70 & 6.70 \\
\hline 3PL04 & 1.90 & 3.10 & 4.30 & 1.90 & 3.10 & 4.30 & 1.90 & 3.10 & 4.30 \\
\hline 3PL05 & 1.40 & 2.65 & 3.90 & 1.40 & 2.65 & 3.90 & 1.40 & 2.65 & 3.90 \\
\hline 3PL06 & 1.30 & 2.30 & 3.30 & 1.30 & 2.30 & 3.30 & 1.10 & 2.10 & 3.10 \\
\hline 3PL08 & 4.40 & 5.65 & 6.90 & 5.10 & 6.20 & 7.30 & 5.00 & 6.10 & 7.20 \\
\hline 3PL09 & 2.30 & 3.30 & 4.30 & 2.10 & 3.15 & 4.20 & 2.10 & 3.15 & 4.20 \\
\hline 3PL10 & 4.10 & 5.15 & 6.20 & 4.00 & 5.10 & 6.20 & 3.90 & 5.00 & 6.10 \\
\hline 3PL & \multicolumn{3}{|c|}{ Flexibility and Responsiveness } & \multicolumn{3}{|c|}{ Environmental Pollution } & \multicolumn{3}{|c|}{ Environmental Laws } \\
\hline 3PL01 & 6.00 & 7.15 & 8.30 & 5.70 & 6.70 & 7.70 & 6.30 & 7.35 & 8.40 \\
\hline 3PL02 & 4.10 & 5.15 & 6.20 & 3.90 & 5.15 & 6.40 & 4.20 & 5.25 & 6.30 \\
\hline 3PL03 & 3.90 & 5.00 & 6.10 & 3.90 & 5.00 & 6.10 & 3.90 & 5.00 & 6.10 \\
\hline 3PL04 & 1.90 & 3.10 & 4.30 & 1.90 & 3.10 & 4.30 & 2.00 & 3.25 & 4.50 \\
\hline 3PL05 & 5.90 & 7.10 & 8.30 & 2.70 & 3.95 & 5.20 & 5.90 & 6.95 & 8.00 \\
\hline 3PL06 & 1.10 & 2.10 & 3.10 & 3.90 & 5.15 & 6.40 & 1.50 & 2.60 & 3.70 \\
\hline 3PL07 & 2.40 & 3.50 & 4.60 & 3.20 & 4.55 & 5.90 & 3.30 & 4.40 & 5.50 \\
\hline 3PL08 & 5.00 & 6.10 & 7.20 & 5.00 & 6.10 & 7.20 & 5.00 & 6.10 & 7.20 \\
\hline 3PL09 & 2.10 & 3.15 & 4.20 & 2.10 & 3.15 & 4.20 & 2.10 & 3.15 & 4.20 \\
\hline 3PL10 & 3.90 & 5.00 & 6.10 & 3.90 & 5.00 & 6.10 & 3.90 & 5.00 & 6.10 \\
\hline
\end{tabular}


Table A2. Cont.

\begin{tabular}{|c|c|c|c|c|c|c|c|c|c|}
\hline \multirow{2}{*}{$\frac{3 P L}{3 P L 01}$} & \multicolumn{3}{|c|}{ Green Operation } & \multicolumn{3}{|c|}{ Health and Safety } & \multicolumn{3}{|c|}{ Voice of Customer } \\
\hline & 6.20 & 7.45 & 8.70 & 5.00 & 6.10 & 7.20 & 5.00 & 6.10 & 7.20 \\
\hline 3PL02 & 3.90 & 5.15 & 6.40 & 3.50 & 4.55 & 5.60 & 3.50 & 4.55 & 5.60 \\
\hline 3PL03 & 3.90 & 5.00 & 6.10 & 3.90 & 5.00 & 6.10 & 3.90 & 5.00 & 6.10 \\
\hline 3PL05 & 6.40 & 7.60 & 8.80 & 5.60 & 6.80 & 8.00 & 5.60 & 6.80 & 8.00 \\
\hline 3PL06 & 1.30 & 2.30 & 3.30 & 2.80 & 3.95 & 5.10 & 0.50 & 1.50 & 2.50 \\
\hline 3PL07 & 4.80 & 6.05 & 7.30 & 3.90 & 5.10 & 6.30 & 5.00 & 6.25 & 7.50 \\
\hline 3PL08 & 5.00 & 6.10 & 7.20 & 5.00 & 6.10 & 7.20 & 5.00 & 6.10 & 7.20 \\
\hline 3PL10 & 3.90 & 5.00 & 6.10 & 3.90 & 5.00 & 6.10 & 3.90 & 5.00 & 6.10 \\
\hline 3PL & \multicolumn{3}{|c|}{ Reputation } & \multicolumn{3}{|c|}{ Operational Risk } & \multicolumn{3}{|c|}{ Financial Risk } \\
\hline 3PL01 & 5.00 & 6.10 & 7.20 & 5.00 & 6.10 & 7.20 & 5.00 & 6.10 & 7.20 \\
\hline 3PL02 & 4.50 & 5.55 & 6.60 & 3.50 & 4.55 & 5.60 & 3.70 & 4.85 & 6.00 \\
\hline 3PL03 & 3.90 & 5.00 & 6.10 & 5.90 & 7.00 & 8.10 & 5.90 & 7.00 & 8.10 \\
\hline 3PL04 & 1.90 & 3.10 & 4.30 & 1.90 & 3.10 & 4.30 & 3.10 & 4.30 & 5.50 \\
\hline 3PL05 & 5.90 & 7.10 & 8.30 & 5.60 & 6.80 & 8.00 & 3.50 & 4.70 & 5.90 \\
\hline 3PL06 & 2.20 & 3.20 & 4.20 & 6.90 & 7.90 & 8.90 & 6.30 & 7.40 & 8.50 \\
\hline 3PL08 & 5.00 & 6.10 & 7.20 & 5.00 & 6.10 & 7.20 & 5.00 & 6.10 & 7.20 \\
\hline 3PL09 & 2.10 & 3.15 & 4.20 & 2.10 & 3.15 & 4.20 & 2.70 & 3.75 & 4.80 \\
\hline 3PL10 & 3.90 & 5.00 & 6.10 & 3.90 & 5.00 & 6.10 & 4.50 & 5.60 & 6.70 \\
\hline
\end{tabular}


Table A3. Fuzzy best value $\left(\widetilde{f}_{i}^{+}\right)$and fuzzy worst $\left(\widetilde{f}_{i}^{-}\right)$value of FVIKOR model.

\begin{tabular}{|c|c|c|c|c|c|c|}
\hline \multirow{2}{*}{$\begin{array}{c}\text { Criteria } \\
\text { C11. Logistics cost }\end{array}$} & \multicolumn{3}{|c|}{ Fuzzy Best Value $\left(\widetilde{f}_{i}^{+}\right)$} & \multicolumn{3}{|c|}{ Fuzzy Worst Value $\left(\widetilde{f}_{i}^{-}\right)$} \\
\hline & 6.90 & 7.90 & 8.90 & 1.40 & 2.65 & 3.90 \\
\hline C12. Financial stability & 6.10 & 7.15 & 8.20 & 1.30 & 2.30 & 3.30 \\
\hline $\begin{array}{l}\text { C13. IT and R\&D } \\
\text { systems }\end{array}$ & 6.00 & 7.15 & 8.30 & 1.30 & 2.30 & 3.30 \\
\hline $\begin{array}{l}\text { C14. Network } \\
\text { management }\end{array}$ & 5.30 & 6.40 & 7.70 & 1.30 & 2.30 & 3.30 \\
\hline C21. Quality of service & 5.80 & 6.95 & 8.10 & 1.30 & 2.30 & 3.30 \\
\hline $\begin{array}{l}\text { C22. Reliability and } \\
\text { delivery time }\end{array}$ & 6.10 & 7.30 & 8.50 & 1.10 & 2.10 & 3.10 \\
\hline $\begin{array}{l}\text { C23. Flexibility and } \\
\text { responsiveness }\end{array}$ & 6.00 & 7.15 & 8.30 & 1.10 & 2.10 & 3.10 \\
\hline $\begin{array}{l}\text { C31. Environmental } \\
\text { pollution }\end{array}$ & 1.90 & 3.10 & 4.20 & 5.70 & 6.70 & 7.70 \\
\hline $\begin{array}{c}\text { C32. Environmental } \\
\text { laws }\end{array}$ & 6.30 & 7.35 & 8.40 & 1.50 & 2.60 & 3.70 \\
\hline C33. Green operation & 6.40 & 7.60 & 8.80 & 1.30 & 2.30 & 3.30 \\
\hline C41. Health and safety & 5.60 & 6.80 & 8.00 & 1.50 & 2.75 & 4.00 \\
\hline C42. Voice of customer & 5.60 & 6.80 & 8.00 & 0.50 & 1.50 & 2.50 \\
\hline C51. Operational risk & 6.90 & 7.90 & 8.90 & 1.90 & 3.10 & 4.20 \\
\hline C52. Financial risk & 2.70 & 3.75 & 4.80 & 6.30 & 7.40 & 8.50 \\
\hline
\end{tabular}




\section{References}

1. Pamucar, D.; Chatterjee, K.; Zavadskas, E.K. Assessment of third-party logistics provider using multi-criteria decision-making approach based on interval rough numbers. Comput. Ind. Eng. 2019, 127, 383-407. [CrossRef]

2. Wan, S.P.; Wang, F.; Lin, L.L.; Dong, J.Y. An intuitionistic fuzzy linear programming method for logistics outsourcing provider selection. Knowl. Based Syst. 2015, 82, 80-94. [CrossRef]

3. Wang, C.-N.; Dang, T.-T.; Nguyen, N.-A.-T.; Le, T.-T.-H. Supporting Better Decision-Making: A Combined Grey Model and Data Envelopment Analysis for Efficiency Evaluation in E-Commerce Marketplaces. Sustainability 2020, 12, 10385. [CrossRef]

4. Moshref-Javadi, M.; Hemmati, A.; Winkenbach, M. A truck and drones model for last-mile delivery: A mathematical model and heuristic approach. Appl. Math. Model. 2020, 80, 290-318. [CrossRef]

5. Wang, C.-N.; Dang, T.-T.; Le, T.Q.; Kewcharoenwong, P. Transportation Optimization Models for Intermodal Networks with Fuzzy Node Capacity, Detour Factor, and Vehicle Utilization Constraints. Mathematics 2020, 8, 2109. [CrossRef]

6. The Future of Supply Chain. Available online: https://www.resilience360.dhl.com/wp-content/uploads/2020/07/20200714 _The-Future-of-Supply-Chain.pdf (accessed on 25 February 2021).

7. Boyson, S.; Corsi, T.; Dresner, M.; Rabinovich, E. Managing effective third party logistics relationships: What does it take? J. Bus. Logist. 1999, 20, 73-100.

8. Govindan, K.; Kadziński, M.; Ehling, R.; Miebs, G. Selection of a sustainable third-party reverse logistics provider based on the robustness analysis of an outranking graph kernel conducted with ELECTRE I and SMAA. Omega 2019, 85, 1-15. [CrossRef]

9. Pham, V.-K.; Ngo, A.-T.; Do, T.-T.-H. Evaluation of the Costs through the Logistics Value Chain (LVC) in Vietnam: An AHP Approach. Int. J. Innov. Creat. Chang. 2020, 14, 868-886.

10. Global 3PL Market Size Estimates. Available online: https://www.3plogistics.com/3pl-market-info-resources/3pl-marketinformation/global-3pl-market-size-estimates / ?fbclid=IwAR0tDoF21SxF4m7wQ7OFIN8J8c1wrzQqCH-YSsz5vj6c2ctI7lEA6 mFC9ms (accessed on 25 February 2021).

11. Raut, R.; Kharat, M.; Kamble, S.; Kumar, C.S. Sustainable evaluation and selection of potential third-party logistics (3PL) providers. Benchmark. Int. J. 2018, 25, 76-97. [CrossRef]

12. Jamali, M.B.; Rasti-Barzoki, M. A game theoretic approach to investigate the effects of third-party logistics in a sustainable supply chain by reducing delivery time and carbon emissions. J. Clean. Prod. 2019, 235, 636-652. [CrossRef]

13. Vazifehdan, M.N.; Darestani, S.A. Green logistics outsourcing employing multi criteria decision making and quality function deployment in the petrochemical industry. Asian J. Shipp. Logist. 2019, 35, 243-254. [CrossRef]

14. Aguezzoul, A. Third-party logistics selection problem: A literature review on criteria and methods. Omega 2014, 49, 69-78. [CrossRef]

15. Hou, J.; Su, D. Integration of web services technology with business models within the total product design process for supplier selection. Comput. Ind. 2006, 57, 797-808. [CrossRef]

16. Büyüközkan, G.; Feyzioğlu, O.; Nebol, E. Selection of the strategic alliance partner in logistics value chain. Int. J. Prod. Econ. 2008, 113, 148-158. [CrossRef]

17. Senthil, S.; Srirangacharyulu, B.; Ramesh, A. A robust hybrid multi-criteria decision making methodology for contractor evaluation and selection in third-party reverse logistics. Expert Syst. Appl. 2014, 41, 50-58. [CrossRef]

18. Ayhan, M.B.; Kilic, H.S. A two stage approach for supplier selection problem in multi-item/multi-supplier environment with quantity discounts. Comput. Ind. Eng. 2015, 85, 1-12. [CrossRef]

19. Liou, J.J.; Chuang, Y.T. Developing a hybrid multi-criteria model for selection of outsourcing providers. Expert Syst. Appl. 2010, 37, 3755-3761. [CrossRef]

20. Kannan, G.; Pokharel, S.; Kumar, P.S. A hybrid approach using ISM and fuzzy TOPSIS for the selection of reverse logistics provider. Resour. Conserv. Recycl. 2009, 54, 28-36. [CrossRef]

21. Igoulalene, I.; Benyoucef, L.; Tiwari, M.K. Novel fuzzy hybrid multi-criteria group decision making approaches for the strategic supplier selection problem. Expert Syst. Appl. 2015, 42, 3342-3356. [CrossRef]

22. Rashidi, K.; Cullinane, K. A comparison of fuzzy DEA and fuzzy TOPSIS in sustainable supplier selection: Implications for sourcing strategy. Expert Syst. Appl. 2019, 121, 266-281. [CrossRef]

23. Deng, F.; Xu, L.; Fang, Y.; Gong, Q.; Li, Z. PCA-DEA-Tobit regression assessment with carbon emission constraints of China's logistics industry. J. Clean. Prod. 2020, 271, 122548. [CrossRef]

24. Davoudabadi, R.; Mousavi, S.M.; Sharifi, E. An integrated weighting and ranking model based on entropy, DEA and PCA considering two aggregation approaches for resilient supplier selection problem. J. Comput. Sci. 2020, 40, 101074. [CrossRef]

25. Perçin, S.; Min, H. A hybrid quality function deployment and fuzzy decision-making methodology for the optimal selection of third-party logistics service providers. Int. J. Logist. Res. Appl. 2013, 16, 380-397. [CrossRef]

26. Zarbakhshnia, N.; Soleimani, H.; Ghaderi, H. Sustainable third-party reverse logistics provider evaluation and selection using fuzzy SWARA and developed fuzzy COPRAS in the presence of risk criteria. Appl. Soft Comput. 2018, 65, 307-319. [CrossRef]

27. Sałabun, W.; Watróbski, J.; Shekhovtsov, A. Are MCDA Methods Bench-markable? A Comparative Study of TOPSIS, VIKOR, COPRAS, and PROMETHEE II Methods. Symmetry 2020, 12, 1549. [CrossRef] 
28. Shekhovtsov, A.; Sałabun, W. A comparative case study of the VIKOR and TOPSIS rankings similarity. Procedia Comput. Sci. 2020, 176, 3730-3740. [CrossRef]

29. Palczewski, K.; Sałabun, W. The fuzzy TOPSIS applications in the last decade. Procedia Comput. Sci. 2019, 159, 2294-2303. [CrossRef]

30. Wang, C.-N.; Dang, T.-T.; Nguyen, N.-A.-T. Outsourcing Reverse Logistics for E-Commerce Retailers: A Two-Stage Fuzzy Optimization Approach. Axioms 2021, 10, 34. [CrossRef]

31. Bobar, Z.; Božanić, D.; Djurić, K.; Pamučar, D. Ranking and assessment of the efficiency of social media using the fuzzy AHP-Z number model-fuzzy MABAC. Acta Polytech Hung. 2020, 17, 43-70. [CrossRef]

32. Saaty, T.L. The Analytic Hierarchy Process; McGraw-Hill International: New York, NY, USA, 1980.

33. Demirel, H.; Şener, B.; Yildiz, B.; Balin, A. A real case study on the selection of suitable roll stabilizer type for motor yachts using hybrid fuzzy AHP and VIKOR methodology. Ocean Eng. 2020, 217, 108125. [CrossRef]

34. Wątróbski, J.; Jankowski, J.; Ziemba, P.; Karczmarczyk, A.; Zioło, M. Generalised framework for multi-criteria method se-lection. Omega 2019, 86, 107-124. [CrossRef]

35. MCDM Method Selection Tools. Available online: http://mcda.it/ (accessed on 12 April 2021).

36. Bottani, E.; Rizzi, A. A fuzzy TOPSIS methodology to support outsourcing of logistics services. Int. J. Supply Chain Manag. 2006, 11, 294-308. [CrossRef]

37. Spencer, M.S.; Rogers, D.S.; Daugherty, P.J. JIT systems and external logistics suppliers. Int. J. Oper. Prod. Manag. 1994, 14, 60-74 [CrossRef]

38. Tsai, M.C.; Wen, C.H.; Chen, C.S. Demand choices of high-tech industry for logistics service providers-An empirical case of an offshore science park in Taiwan. Ind. Mark. Manag. 2007, 36, 617-626. [CrossRef]

39. Gao, T.G.; Huang, M.; Wang, Q.; Wang, X.W. Dynamic organization model of automated negotiation for 3PL providers selection. Inf. Sci. 2020, 531, 139-158. [CrossRef]

40. Mavi, R.K.; Goh, M.; Zarbakhshnia, N. Sustainable third-party reverse logistic provider selection with fuzzy SWARA and fuzzy MOORA in plastic industry. Int. J. Adv. Manuf. Technol. 2017, 91, 2401-2418. [CrossRef]

41. Govindan, K.; Jha, P.C.; Agarwal, V.; Darbari, J.D. Environmental management partner selection for reverse supply chain collaboration: A sustainable approach. J. Environ. Manag. 2019, 236, 784-797. [CrossRef] [PubMed]

42. Sasikumar, P.; Haq, A.N. Integration of closed loop distribution supply chain network and 3PRLP selection for the case of battery recycling. Int. J. Prod. Res. 2011, 49, 3363-3385. [CrossRef]

43. Liu, H.T.; Wang, W.K. An integrated fuzzy approach for provider evaluation and selection in third-party logistics. Expert Syst. Appl. 2009, 36, 4387-4398. [CrossRef]

44. Leahy, S.E.; Murphy, P.R.; Poist, R.F. Determinants of successful logistical relationships: A third-party provider perspective. Transp. J. 1995, 35, 5-13.

45. Göl, H.; Çatay, B. Third-party logistics provider selection: Insights from a Turkish automotive company. Supply Chain Manag. 2007, 12, 379-384. [CrossRef]

46. Jharkharia, S.; Shankar, R. Selection of logistics service provider: An analytic network process (ANP) approach. Omega 2007, 35, 274-289. [CrossRef]

47. Goebel, P.; Reuter, C.; Pibernik, R.; Sichtmann, C. The influence of ethical culture on supplier selection in the context of sustainable sourcing. Int. J. Prod. Econ. 2012, 140, 7-17. [CrossRef]

48. Ni, J.; Chu, L.K.; Yen, B.P. Coordinating operational policy with financial hedging for risk-averse firms. Omega 2016, 59, 279-289. [CrossRef]

49. Thakkar, J.; Deshmukh, S.G.; Gupta, A.D.; Shankar, R. Selection of third-party logistics (3PL): A hybrid approach using interpretive structural modeling (ISM) and analytic network process (ANP). Int. J. Supply Chain Forum Taylor Fr. 2005, 6, 32-46. [CrossRef]

50. Vaidyanathan, G. A framework for evaluating third-party logistics. Commun. Acm 2005, 48, 89-94. [CrossRef]

51. Ying, W.; Dayong, S. Multi-agent framework for third party logistics in E-commerce. Expert Syst. Appl. 2005, 2, 431-436. [CrossRef]

52. Singh, R.K.; Kumar, R.; Shankar, R. Supply chain management in SMEs: A case study. Int. J. Manuf. Res. 2012, 7, 165-180. [CrossRef]

53. Agrawal, S.; Singh, R.K.; Murtaza, Q. Outsourcing decisions in reverse logistics: Sustainable balanced scorecard and graph theoretic approach. Resour. Conserv. Recycl. 2016, 108, 41-53. [CrossRef]

54. Efendigil, T.; Önüt, S.; Kongar, E. A holistic approach for selecting a third-party reverse logistics provider in the presence of vagueness. Comput. Ind. Eng. 2008, 54, 269-287. [CrossRef]

55. Anderson, E.J.; Coltman, T.; Devinney, T.M.; Keating, B. What drives the choice of a third-party logistics provider? J. Supply Chain Manag. 2011, 47, 97-115. [CrossRef]

56. Choy, K.L.; Chow, H.K.; Tan, K.H.; Chan, C.K.; Mok, E.C.; Wang, Q. Leveraging the supply chain flexibility of third party logistics-Hybrid knowledge-based system approach. Expert Syst. Appl. 2008, 35, 1998-2016. [CrossRef]

57. Da Silveira Guimarães, J.L.; Salomon, V.A.P. ANP applied to the evaluation of performance indicators of reverse logistics in footwear industry. Procedia Comput. Sci. 2015, 55, 139-148. [CrossRef]

58. Mitra, S.; Karathanasopoulos, A.; Sermpinis, G.; Dunis, C.; Hood, J. Operational risk: Emerging markets, sectors and measurement. Eur. J. Oper. Res. 2015, 241, 122-132. [CrossRef]

59. Zadeh, L.A. Fuzzy Sets. Inf. Control 1965, 8, 338-358. [CrossRef] 
60. Sun, C.C. A performance evaluation model by integrating fuzzy AHP and fuzzy TOPSIS methods. Expert Syst. Appl. 2010, 37, 7745-7754. [CrossRef]

61. Chang, D.Y. Applications of the extent analysis method on fuzzy AHP. Eur. J. Oper. Res. 1996, 95, 649-655. [CrossRef]

62. Chang, T.H. Fuzzy VIKOR method: A case study of the hospital service evaluation in Taiwan. Inf. Sci. 2014, 271, 196-212. [CrossRef]

63. Baležentis, A.; Baležentis, T.; Brauers, W.K. Personnel selection based on computing with words and fuzzy multimoora. Expert Syst. Appl. 2012, 39, 7961-7967. [CrossRef]

64. Vietnam Logistics Industry: Risks and Challenges. Available online: https://vietnamcredit.com.vn/news/vietnam-logisticsindustry-risks-and-challenges_13632 (accessed on 25 February 2021).

65. 3PL Networks in Vietnam: How to Engage Partners to Boost Sales. Available online: https://www.vietnam-briefing.com/news / 3pl-networks-in-vietnam-engage-partners-boost-sales.html/ (accessed on 25 February 2021).

66. Dang, V.L.; Yeo, G.T. Weighing the key factors to improve Vietnam's logistics system. Asian J. Shipp. Logist. 2018, 34, 308-316. [CrossRef]

67. Chou, Y.C.; Yen, H.Y.; Dang, V.T.; Sun, C.C. Assessing the Human Resource in Science and Technology for Asian Countries: Application of Fuzzy AHP and Fuzzy TOPSIS. Symmetry 2019, 11, 251. [CrossRef]

68. Buckley, J.J. Ranking Alternatives Using Fuzzy Numbers. Fuzzy Sets Syst. 1985, 15, 21-31. [CrossRef]

69. How COVID-19 Has Transformed the Logistics and 3PL Industry. Available online: https://www.supplychaindigital.com/ logistics-1/how-covid-19-has-transformed-logistics-and-3pl-industry (accessed on 25 February 2021).

70. Sarkis, J. Supply chain sustainability: Learning from the COVID-19 pandemic. Int. J. Oper. Prod. Manag. 2020, 41, 63-73. [CrossRef]

71. Chen, Z.; Yang, W. An MAGDM based on constrained FAHP and FTOPSIS and its application to supplier selection. Math. Comput. Model. 2011, 54, 2802-2815. [CrossRef]

72. Shekhovtsov, A.; Kozlov, V.; Nosov, V.; Sałabun, W. Efficiency of Methods for Determining the Relevance of Criteria in Sustainable Transport Problems: A Comparative Case Study. Sustainability 2020, 12, 7915. [CrossRef]

73. Wang, C.-N.; Dang, T.-T.; Tibo, H.; Duong, D.-H. Assessing Renewable Energy Production Capabilities Using DEA Window and Fuzzy TOPSIS Model. Symmetry 2021, 13, 334. [CrossRef]

74. Sałabun, W.; Urbaniak, K. A new coefficient of rankings similarity in decision-making problems. In International Conference on Computational Science; Springer: Cham, Switzerland, 2020; pp. 632-645. 